1

\title{
Environmental Assessment \\ for the \\ Transfer of the DP Road Tract \\ to the County of Los Alamos
}

Los Alamos, New Mexico

\section{Final Document}

Date Prepared \January 23, 1997

Prepared by: $\quad$ US Department of Energy

Los Alimos Area Office 


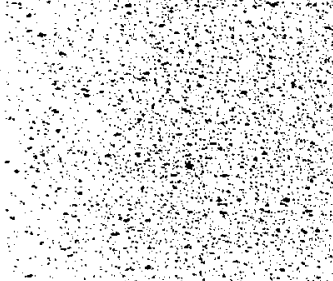

\begin{tabular}{lll}
$n$ \\
\hline
\end{tabular}

,

$+2+,+4$,

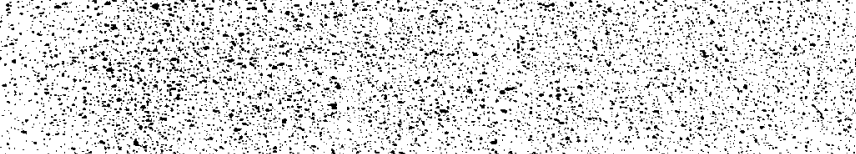

$3+1$,

$3+3+4$,

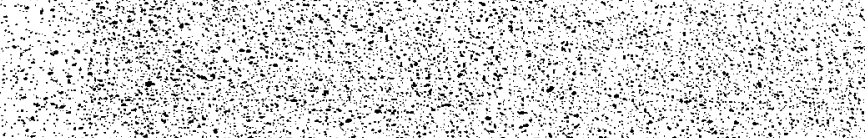

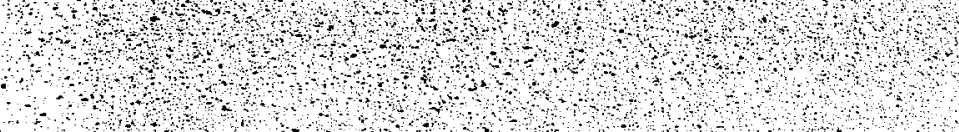

स.

I

-

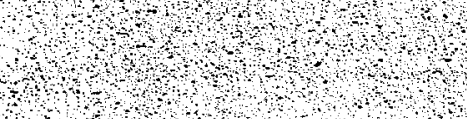

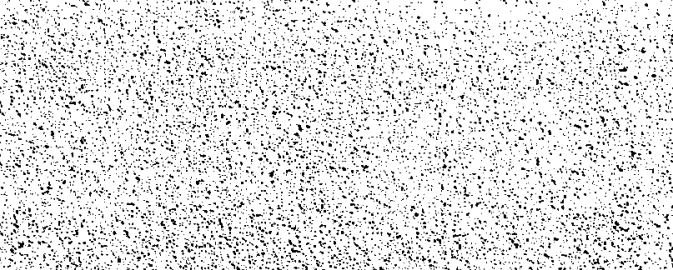




\section{DISCLAIMER}

This report was prepared as an account of work sponsored by an agency of the United States Government. Neither the United States Government nor any agency thereof, nor any of their employees, make any warranty, express or implied, or assumes any legal liability or responsibility for the accuracy, completeness, or usefulness of any information, apparatus, product, or process disclosed, or represents that its use would not infringe privately owned rights. Reference herein to any specific commercial product, process, or service by trade name, trademark, manufacturer, or otherwise does not necessarily constitute or imply its endorsement, recommendation, or favoring by the United States Government or any agency thereof. The views and opinions of authors expressed herein do not necessarily state or reflect those of the United States Government or any agency thereof. 


\section{DISCLAIMER}

Portions of this document may be illegible in electronic image products. Images are produced from the best available original document. 


\section{TABLE OF CONTENTS}

ACRONYMS AND TERMS $\ldots \ldots \ldots \ldots \ldots \ldots \ldots \ldots \ldots \ldots \ldots \ldots \ldots \ldots \ldots \ldots \ldots \ldots, \ldots \ldots$

EXECUTTVE SUMMLARY $\ldots \ldots \ldots \ldots \ldots \ldots \ldots \ldots \ldots \ldots \ldots \ldots \ldots \ldots \ldots \ldots \ldots \ldots \ldots \ldots \ldots$

1.0 PURPOSE AND NEED FOR AGENCY ACTION $\ldots \ldots \ldots \ldots \ldots \ldots \ldots \ldots \ldots \ldots \ldots \ldots$

1.1 Introduction $\ldots \ldots \ldots \ldots \ldots \ldots \ldots \ldots \ldots \ldots \ldots \ldots \ldots \ldots \ldots \ldots \ldots \ldots \ldots \ldots \ldots \ldots \ldots \ldots \ldots \ldots, \ldots \ldots \ldots$

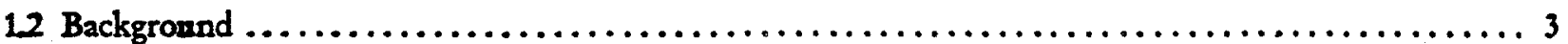

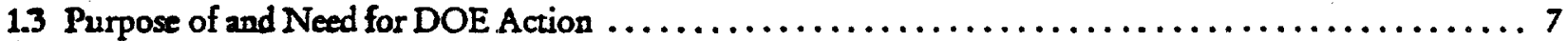

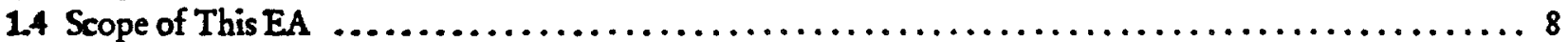

1.5 Public Involvement $\ldots \ldots \ldots \ldots \ldots \ldots \ldots \ldots \ldots \ldots \ldots \ldots \ldots \ldots \ldots \ldots \ldots \ldots \ldots \ldots$

20 DESCRIPTION OF THE PR.OPOSED ACTION AND ALTERNATIVES $\ldots \ldots \ldots \ldots \ldots \ldots \ldots 11$

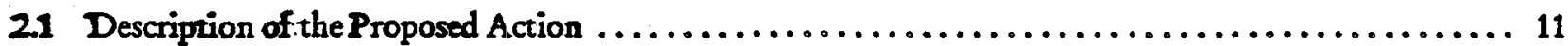

2.1.1 Location and Description of Land Tract $\ldots \ldots \ldots \ldots \ldots \ldots \ldots \ldots \ldots \ldots \ldots \ldots \ldots \ldots \ldots$

2.1.2 Proposed DP Road Tract Uses $\ldots \ldots \ldots \ldots \ldots \ldots \ldots \ldots \ldots \ldots \ldots \ldots \ldots \ldots \ldots \ldots \ldots \ldots \ldots$

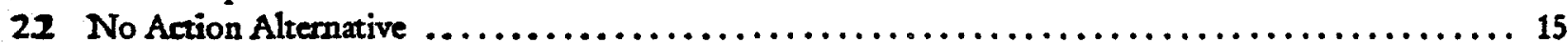

23 Alternatives Considered But Dismissed from Further Consideration $\ldots \ldots \ldots \ldots \ldots \ldots \ldots \ldots \ldots . \ldots$

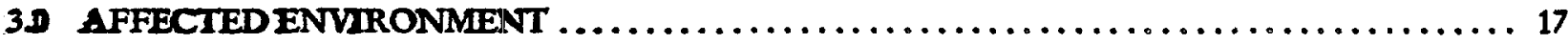

3.1 Regional Setting $\ldots \ldots \ldots \ldots \ldots \ldots \ldots \ldots \ldots \ldots \ldots \ldots \ldots \ldots \ldots \ldots \ldots \ldots \ldots \ldots \ldots \ldots \ldots \ldots \ldots, 17$

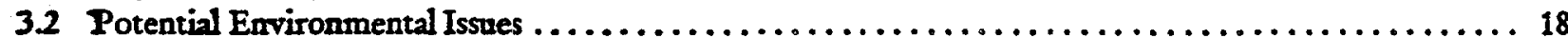

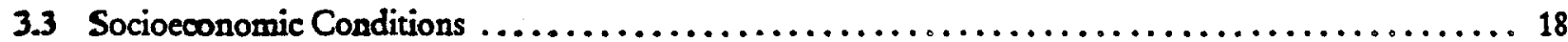

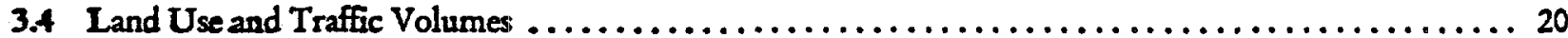

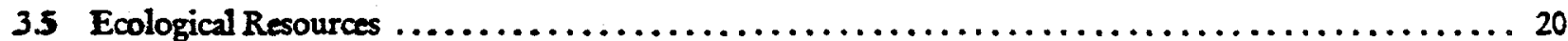

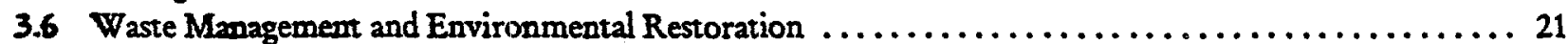

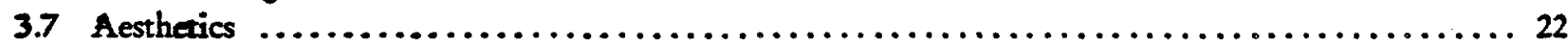

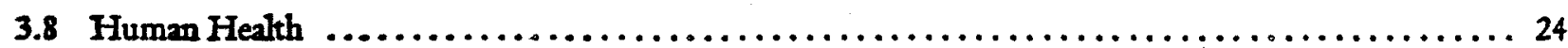

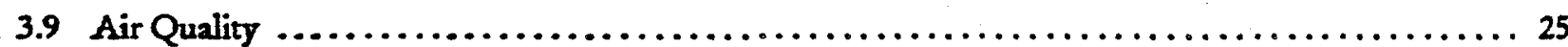

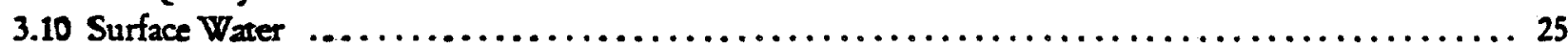

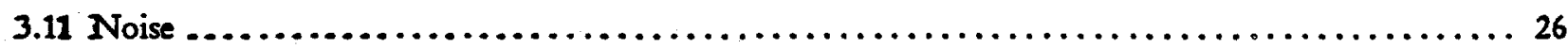

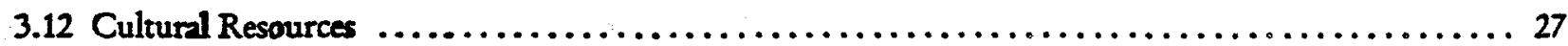

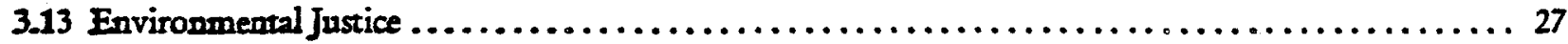

Lo ENVIRONMENTAL CONSEQUENCES $\ldots \ldots \ldots \ldots \ldots \ldots \ldots \ldots \ldots \ldots \ldots \ldots \ldots \ldots \ldots \ldots$

4.1 Proposed Action $\ldots \ldots \ldots \ldots \ldots \ldots \ldots \ldots \ldots \ldots \ldots \ldots \ldots \ldots \ldots \ldots \ldots \ldots \ldots \ldots \ldots \ldots \ldots \ldots \ldots \ldots .29$

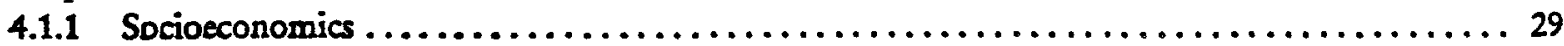

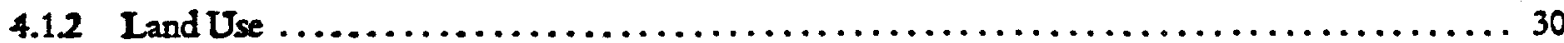

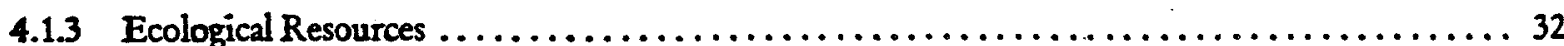

4.1.4 Waste Management and Environmental Restoration $\ldots \ldots \ldots \ldots \ldots \ldots \ldots \ldots \ldots \ldots \ldots \ldots \ldots$

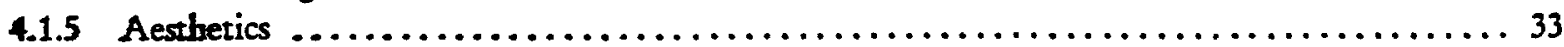

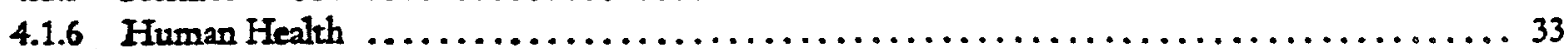

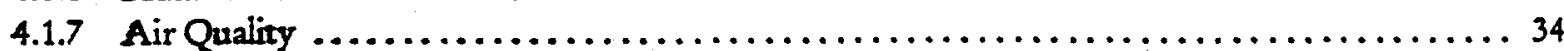

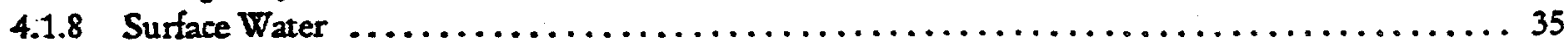

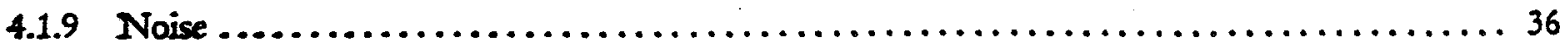




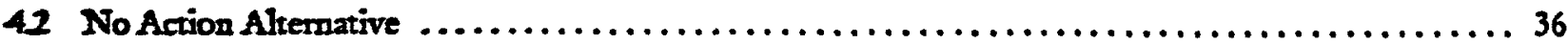

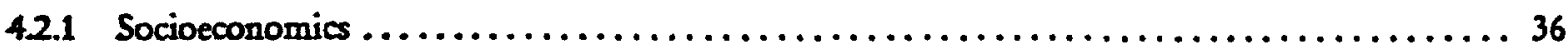

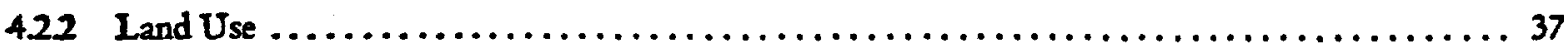

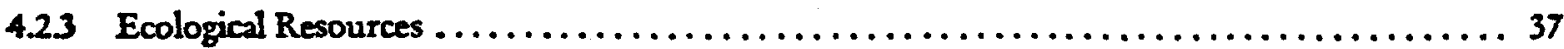

4.2.4 Waste Management and Environmental Restoration $\ldots \ldots \ldots \ldots \ldots \ldots \ldots \ldots \ldots \ldots \ldots \ldots \ldots$

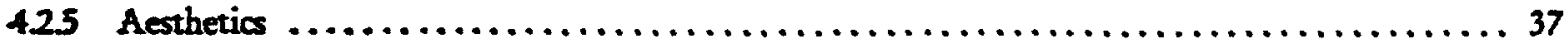

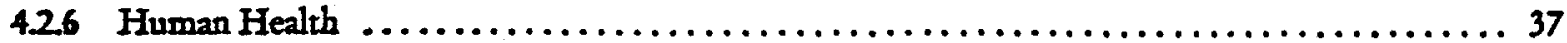

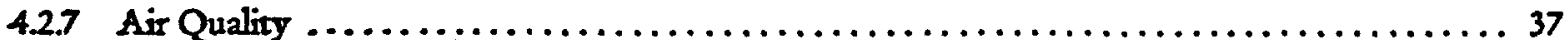

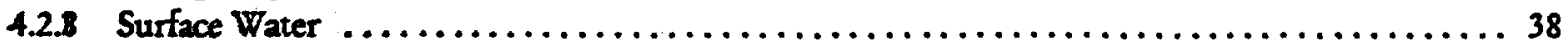

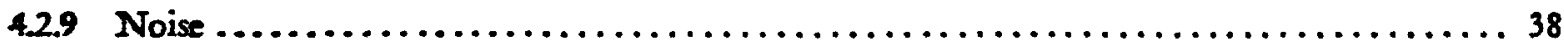

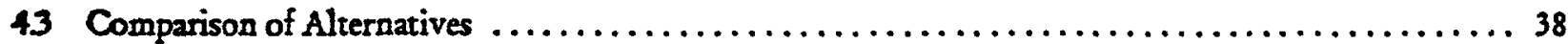

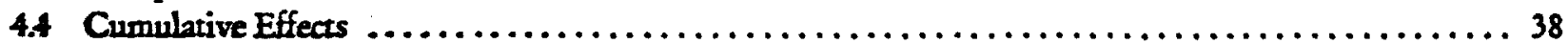

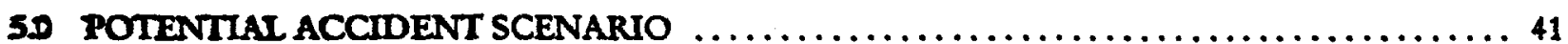

6.D REGULATORY REQUIREMENTS AND CONSULTATIONS $\ldots \ldots \ldots \ldots \ldots \ldots \ldots \ldots \ldots$

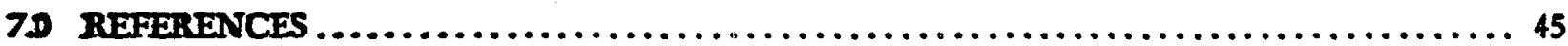

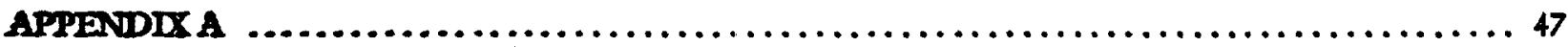

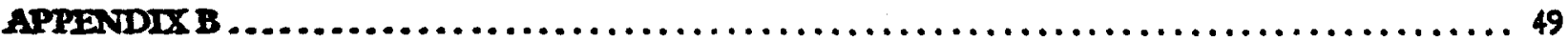




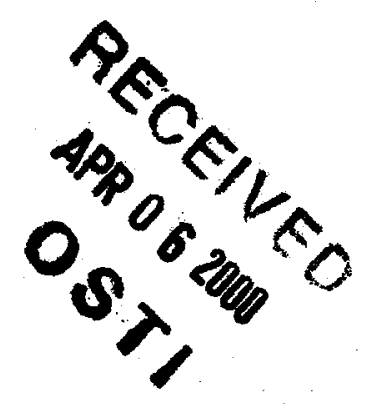

Department of Energy

Finding of No Significant Impact

Transfer of the DP Road Tract to the

County of Los Alamos

Los Alamos, New Mexico

U. S. Department of Energy

Los Alamos Area Office

528 35th Street

Los Alamos, NM 87544 


\section{DEPARTMENT OF ENERGY (DOE) \\ FINDING OF NO SIGNIFICANT. IMPACT}

\section{Transfer of the DP Road Tract to the County of Los Alamos}

FINAL ENVIRONMENTAL ASSESSMENT: The Environmental Assessment (EA) for the Transfer of the DP Road Tract to the County of Los Alamos (DOE/EA-1184) (attached) provides sufficient evidence and analysis to determine that a finding of no significant impact is appropriate for this action. The DOE documents environmental consequences of the proposed action in this EA. There are other issues asscoiated with this action that are not in and are not meant to be in the EA. The EA documents the evidence and analysis in the following chapters: 1. Purpose and Need for Agency Action; 2. Description of the Proposed Action and Alternatives; 3. Affected Environment; 4. Environmental Consequences; 5. Potential Accident Scenarios; and 6. Regulatory Requirements and Consultations.

PREDECISIONAL DRAFT REVIEW \& COMMENT: On November 15, 1996, the Department of Energy (DOE) invited review and comment on the predecisional EA from the State of New Mexico and four American Indian Tribes: Cochiti, Jemez, Santa Clara and San Ildefonso ( sometimes referred to as the four accord pueblos because each tribe has entered into an accord with the DOE). In addition, DOE made the predecisional draft EA available to Los Alamos County and the general public at the same time it was provided to the State of New Mexico and the four accord pueblos by placing it in the DOE Public Reading Rooms within the Los Alamos National Laboratory Outreach Center and Reading Room in Los Alamos, and the TVI-Main Campus Library in Albuquerque: Also, local 
stakeholder groups were notified of the availability of the predecisional draft on November 15, 1996. The public comment period on this EA was extended three weeks because of stakeholder requests.

Comments were received from six stakeholders. These comments were addressed in the Final EA, and individual responses to the comments were sent to the respondents.

FINDING: Based on the EA that analyzes the consequences of the relevant issues of environmental concern and the concerns of the stakeholders, the United States Department of Energy finds that there would be no significant impact from proceeding with its proposal to transfer to the County of Los Alamos a 28-acre land tract located on DP Road for their development and use as a business park or for light industrial purposes. DOE makes this Finding of No Significant Impact pursuant to the National Environmental Policy Act of 1969 (NEPA); 42 U.S.C. $\$ 4321$, et seq., the Council on Environmental Quality Regulations for Implementing the Procedural Provisions of NEPA, 40 C.F.R. Part 1500; and the DOE National Environmental Policy Act Implementing Procedures, 10 C.F.R. Part 1021. The proposed action does not constitute a major federal action that would significantly affect the human environment within the mandate of NEPA. Therefore, no environmental impact statement is required for this proposal.

Signed in Los Alamos, New Mexico this $23^{r d}$ day of 1997.

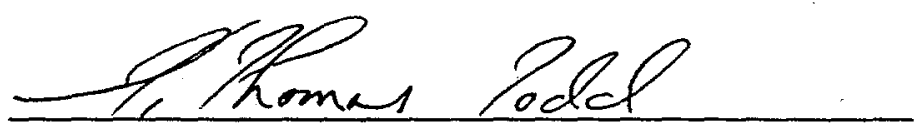

G. Thomas Todd

Area Manager Los Alamos Area Office 
FOR FURTHER INFORMATION CONTACT: For further information on this proposal, this Finding Of No Significant Impact (FONSI), or the DOE's National Environmental Policy Act (NEPA) review program concerning proposals at LANL, please contact:

\author{
Elizabeth Withers, NEPA Compliance Officer \\ Los Alamos Area Office \\ U.S. Department of Energy \\ 528 35th Street \\ Los Alamos NM 87544 \\ (505) 667-8690
}

Copies of this FONSI (with the Environmental Assessment attached) will be made available for public review at the Los Alamos National Laboratory Outreach Center and Reading Room, 1450 Central Avenue, Suite 101, Los Alamos, New Mexico, 87544 at $\{505\}$ 665-2127 or (800) 543-2342. Copies will also be made available in the DOE Public Reading Room, located in the TVI-Main Campus Library, 525 Buena Vista SE, Albuquerque, New Mexico, 87106 at (505) 224-3000. 


\section{ACRONYMS and TERMS}

AEA Atomic Enery Act

AECA Atomic Energy Comnzunity Act

AIRDOSE EPA air quality model

BMP Best Management Practices

CAA Clean Air Act

CEQ Council on Environmental Quality

CERCLA Comprebensive Environmental

Response, Compensation, and Liability

Act

CFR . Code of Federal Regulations

cm centimeter

CMR Chemical and Metallurgy Research

CO Carbon Monoxide

DED Decontamination and

Decommissioning

DAA Defense Autborization Act

DARHT Dual Axis Radiograpibic

Hydrodymamic Test

dB Decibel

dBA A-weigbted Decibels

DOE Department of Energy

EA Environmental Assessment

EDE Effective Dose Equivalents

EIS Environmental Impact Statement

EPA U.S Environmental Protection

Agency

ER Environmental Restoration

ERPG-3 Emergency Response Planning

Guideline

F

Degrees Fabrenbeit
FONSI Finding of No Significant Impact

ft feet

$f^{2} \quad$ square feet

GSA General Services Administration

in. inch

km kilometer

kV kilovolt

kWb kilowatt bours

LANL Los Alamos National Laboratory

LANSCE Los Alamos Neutron Scattering Center and Energy Research Programs

m meter

$m^{3} \quad$ cubic meter

MAR Material at Risk

MEI Maximum Exposed Individual

mi mile

NEPA National Environmental Policy Act

NHPA National Historic Preservation Act

NMED New Mexico Environment

Department

$\mathrm{NO}_{2} \quad$ Nitrogen Dioxide

NPDES National Pollutant Discbarge

Elimination System

NWI National Wetlands Inventory

OEL Occupational Exposure Limit

ORNL Oak Ridge National Laboratory

OSHA Occupational Safery \& Health

Administration

PHERMEX Pulsed High Energy Machine Emitting $X \cdot$ Rays 


\section{PN Particulate Matter}

PRS Potential Release Site

RED Research and Development

RCRA Resource Conservation and Recovery

Aat

ROI Region of Influence

SAR Safety Analysis Report

SHPO State Historic Preservation Officer

$\mathrm{SO}_{2} \quad$ Sulpbur Dioxide

SWEIS Site-Wide Environmental Impact

Statement

SWMU Solid Waste Management Unit

SWSC Sanitary Wastewater Systems

Consolidation

TEE Threatened and Endangered

IA Tecbnical Area

TCP Traditional Cultural Properties

TES Tbreatened, Endangered, or Sensitive

TLDs Thermoluminescent Dosimeters

INI Trinitrotoluene

ISFF Tritium Science and Fabrication

Facility

TSP Total Suspended Particulates

USC United States Code

USFWS United States Fish and Wildlife Service

VCA Voluntary Corrective Action

VOC Volatile Organic Compounds

ye cubic yards

y1 year 


\section{EXECUTIVE SUMMARY}

The National Environmental Policy Act of 1969 (NEPA), as amended (42 U.S.C. 4321 et seq.), requires the Department of Energy (DOE) to consider the environmental consequences of Proposed Actions before decisions are made. The purpose of an Environmental Assessment (EA) is to provide the DOE with sufficient evidence and analysis to determine whether to prepare an Environmental Impact Statement (EIS) or a Finding of No Significant Impact (FONSI). Additional considerations (such as costs, timing, or non-environmental legal issues) that influence DOE decisions are not analyzed in this EA. As part of its initiative to fulfill its responsibilities to provide support for the County of Los Alamos (the County), in northern New Mexico, as an Atomic Energy Community, while simultaneously fulfilling its obligations under the Atomic Energy Act of 1954 and the Atomic Energy Community Act of 1955, the U.S. Department of Energy (DOE) proposes to transfer ownership of the undeveloped, so called, DP Road property to the County.

The Proposed Action is intended to accelerate economic development activities within the County through the employment opportunities offered subsequent to the attainment of additional property ownership, development, and its following use.

A “stiding-seale approach is the basis for effects analysis in this Environmental Assessment (EA). That is, certain aspects of implementing the Proposed Action have a greater potential for creating adverse environmental effects than others; therefore, they are discussed in greater detail in this EA than those aspects of implementing the action that have little potential for affect.

The Proposed Action is estimated to result in an increase of as many as $\mathbf{4 5 0}$ new direct jobs and as many as $\mathbf{5 8 5}$ indirect jobs from the development of the DP Road tract. Transfer of this tract would permanently reduce the size of Los Alamos National Laboratory (LANL) by approximately 0.1 percent. Approximately 12 hectares (28 acres) would be changed from an undeveloped to a developed status. This would result in an equivalent loss of wildlife habitat.

Under the No Action Alternative, no transfer of Federal lands would occur. No new jobs would be created from proposed development activities. Undeveloped lands would remain in their current condition.

A hypothetical accident was analyzed that evaluated potential radiological dose to the public at the DP Road tract from IANL operations. The dose to the hypothetical worker population of $450 \mathrm{new}$ employees could result in an increase of approximately three latent cancer fatalities in the population.

The cumulative effects of the Proposed Action as well as reasonably foreseeable related actions would result in no adverse health effects. Additional economic development would be expected to occur. 
This Page Intentionally Left Blank 


\subsection{PURPOSE AND NEED FOR AGENCY ACTION}

\subsection{Introduction}

As part of îts iniriative to fulfill its responsibilities to provide support for the County of Los Alamos (County), New Mexico, as an A.tomic Energy Community, while simultaneously fulfilling its obligations to enhance the self-sufficiency of the County under the Atomic Energy Community Act (AECA) of 1955 and fulfilling its obligations under the Atomic Energy Act (AEA) of 1954, the Department of Energy (DOE) proposes to transfer ownership of the undeveloped DP Road property to the County for future business park or light industrial development purposes. The DP Road tract is located at the edge of Los Alamos Townsite within Los Alamos County (Figure 1-1).

The National Environmental Policy Act of 1969 (NEPA), as amended (42 U.S.C. 4321 et seq.), Iequires the Department of Energy (DOE) to consider the environmental consequences of Proposed Actions before decisions are made. In complying with NEPA, DOE follows the Council on Environmental Quality (CEQ) regulations (40 CFR 1500-1508) and DOE's own NEPA implementing procedures (10 CFR 1021). The purpose of an Environmental Assessment (EA) is to provide the DOE with sufficient evidence and analysis to determine whether to prepare an Environmental Impact Statement (EIS) or a Finding of No Significant Impact (FONSI). In this case, the DOE decision to be made is whether or not to transfer its ownership of the subject land tract by deed. This type of action does not in and of itself result in eavironmental effects; however, the DOE has considered the planned use of the land and the ensuing posential environmental effects subsequent to the transfer of ownership in its decision making process. Therefore, DOE is evaluating its decision in light of the contemplated land use as outlined by County officials that could only occur if the DOE decides to transfer its ownership of the subject land tract. The objectives of this EA are (1) to describe the baseline environmental conditions at the tract location involved in the Proposed Action, (2) to analyze potential generic effects to the baseline environment from land development activities and future occupants' operations occurring at the tract location, and (3) to identify and characterize cumulative effects of future anticipated uses of the tract involved in the Proposed Action together with those of surrounding properties. In addition, the EA provides DOE with environmental information that would be used in preparing appropriate notices which would serve to preserve the integrity of the human environment and natural ecosystems should the DOE decide to proceed with the Proposed Action.

\subsection{Background}

The general Los Alamos, New Mexico area was occupied primarily by small ranches and farms until 1942 when the nation underwent a dramatic change upon its entry into World War II. At that time, the Los Alamos Ranch School (then the single largest private land holding in the Los Alamos area), together with portions of surrounding properties, was chosen as the location of a secret research and development facility for the world's first nuclear weapon by the Federal government, the Manhattan District of the Army Corps of Engineers. The original facility and its operations were referred to as Project Y of the Manhattan Project, and later were redesignated as the Los Alamos Scientific Laboratory. The facitiny's name was changed during the 1980 s to Los Alamos National Laboratory (LANL) (Figure 1-1). Additionally, the Federal agency with management responsibility for LANL has evolved from the post-World War II Atomic Energy Commission and the Energy Research and 


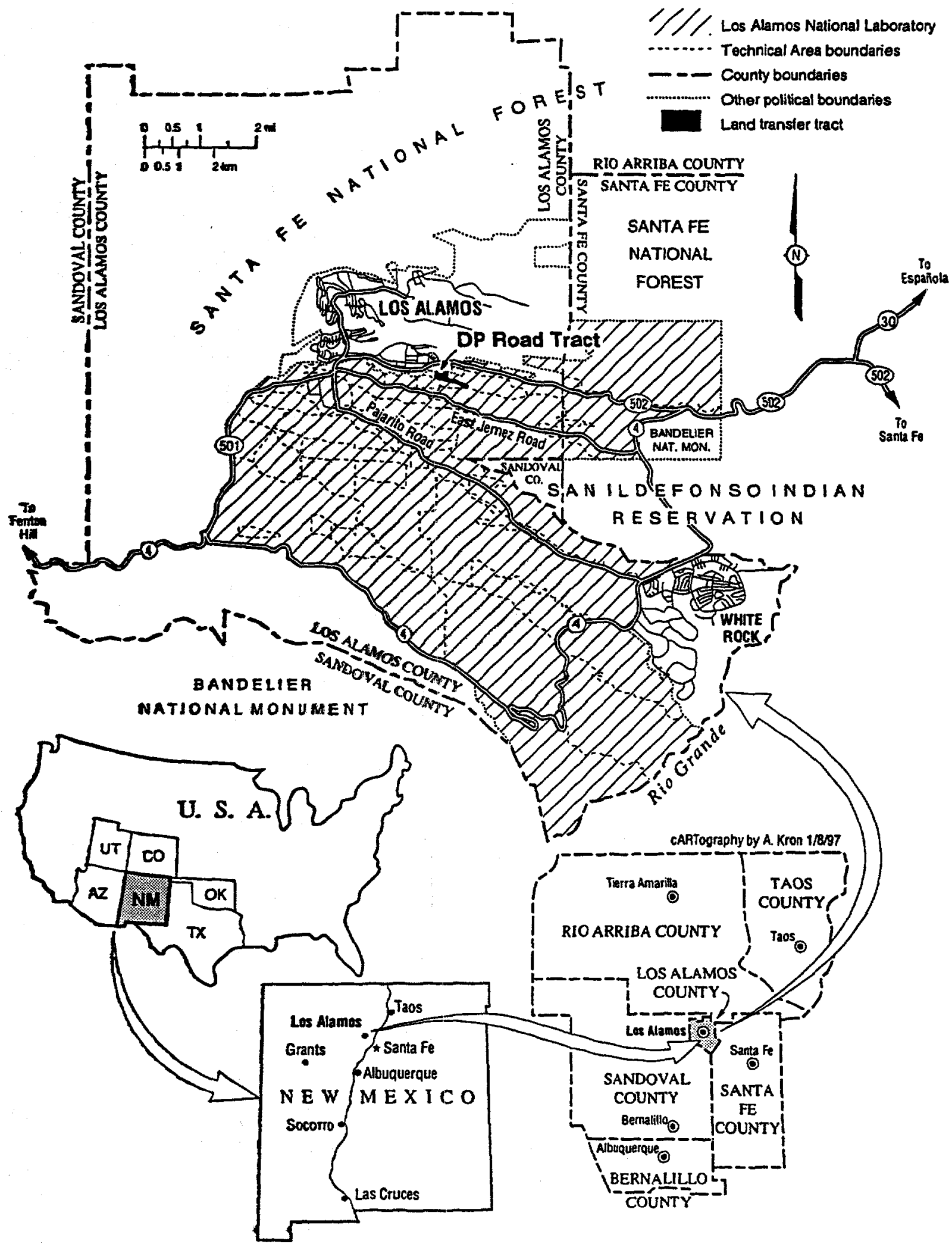

Figure 1-1. Location of Los Alamos National Laboratory and land transfer tract. 
Development Administration to the Department of Energy. For over 50 years, Federal activities conducted at the LANL site have strongly influenced the social and economic characteristics of the Los Alamos community and the surrounding region.

Construction of LANL facilities and structures within the present-day designated boundaries began in the 1940s, with all of the main laboratory functions having now been moved onto the mesas located south of the Los Alamos Townsite (Townsite). Over the last forty years, the old laboratory buildings occupied by the Manhatran Project were demolished and almost all of the Townsite area has undergone evacuation and decontamination from historical laboratory uses. Technical Area (TA) 21 is the last LANL site conducting on-going LANL research and development missions in immediate proximity to the Townsite, (Figure 1-2). TA-21 operations are gradually being moved to other portions of LANL or eliminated.

Under the Atomic Energy Community Act of 1955 (AECA, 42 USC \$ 2391), the Federal government recognized its responsibility to provide support for a specified time period to agencies or municipalities that were very strongly affected by their proximity to facilities that are part of the nation's nuclear weapons complex, namely, the three so-called Atomic Energy Communities (Oak Ridge, Tennessee; Richland, Washington; and Los Alamos, New Mexico), while they achieved self-sufficiency. These communities were established as wholly government-owned communities in which all municipal, educational, medical, housing, and recreational facilities were provided by the federal government. Under the provisions of AECA, national policies were established regarding the obligations of the United States to the three Atomic Energy Communities, and these policies were directed at terminating Federal government ownership and management of the communities by facilitating the establishmemt of local self-government; providing for the orderly transfer to local entities of municipal functions; and providing for the orderly sale to private purchasers of property within these communities with a minimum of dislocation. The establishment of self-government and transfer of infrastructures and land were intended for the purpose of encouraging self-sufficiency of the commmities through the establishment of a broad base for economic development.

In 1949, the New Mexico legislature created Los Alamos County from portions of Sandoval and Santa Fe Counties. The County remained Federal government property, however, until legislation was passed in 1965 that changed the status of the County to a more traditional government entity, and subsequently allowed the DOE to move forward with the transfer and lease of the Federal lands under its management to the County, other government agencies, and to private parties. In 1967, the DOE's predecessor agencies began to transfer ownership of the land tracts, roads, buildings, and some of the utility systems managed by LANL to the County to be made available for public use. The Federal government also established leases for some small tracts of land that it owned within the County.

Because of changes in mission and underutilization of some DOE facilities, DOE's land and facility use and transfer policy has continued to change in recent years. In December 1993, DOE directed agency officials at each of its major sites to "implement a site-specific process to identify future-use options based on the unique characteristics of the site and stakeholder needs" (Pearman and Grumbly 1993). Subsequent to this directive, DOE Secretary Hazel O'Leary recently issued a Land and Facility Use Policy for reming lands to public wee, stimulating local economies, ensuring public participation, and protecting natural resources. 


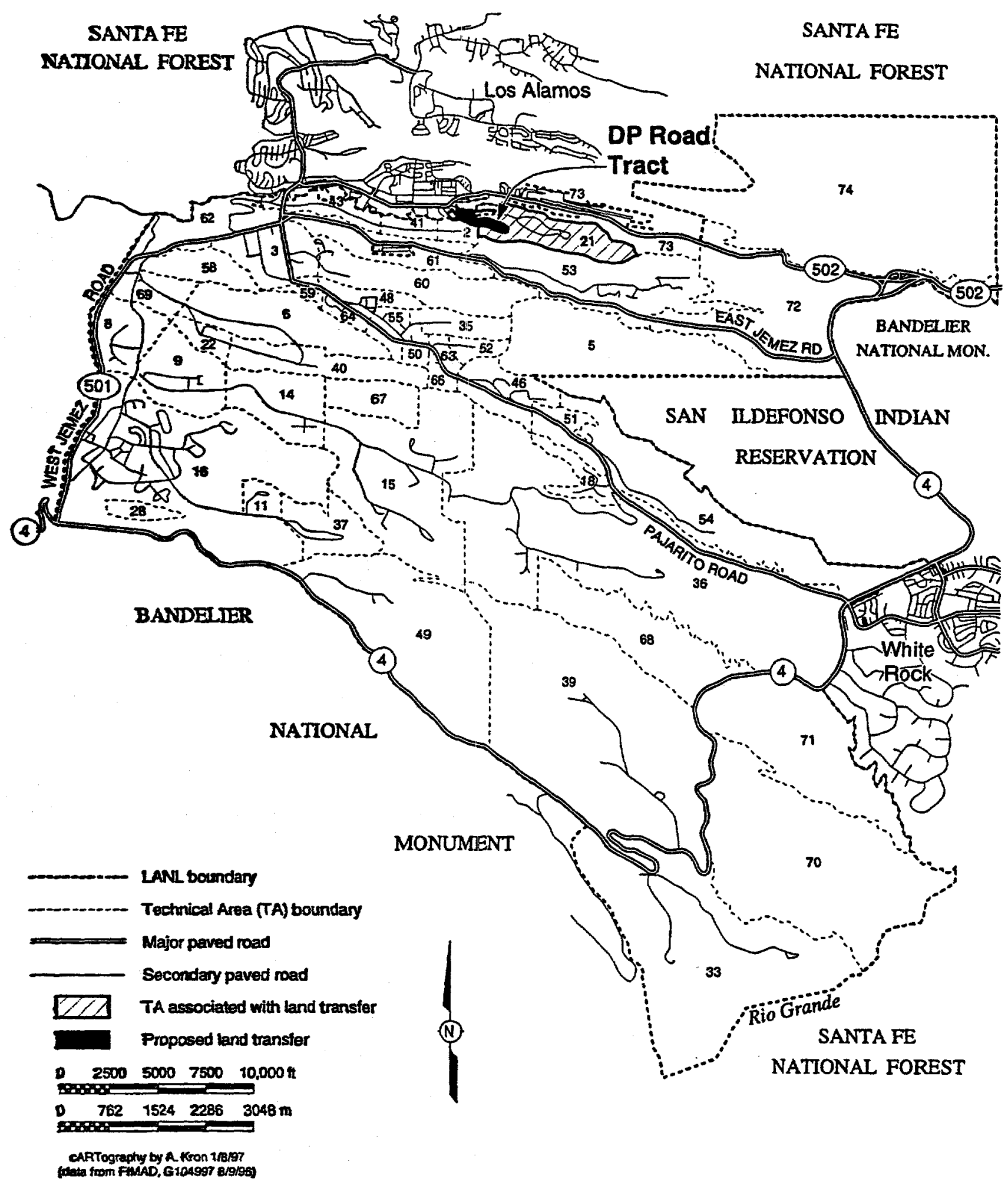

Figure 1-2 Los Alamos National Laboratory showing TAs affected by the land transfer. 
This policy statement reiterates a commitment to integrating agency and community interests, as has been practiced in the County by the DOE for at least 40 years. Since the 1950 s, DOE and its predecessor agencies have sold or transferred approximately 11,271 hectares (27,850 acres) of land from DOE management to the local community. These land transactions involved about 42 percent of the 26,784 hectares (66,181 acres) of original Manhattan Project land area and neighboring properties obtained by the Federal government from 1942 through 1948 in the Los Alamos area. More than half of these transfers were to private parties for housing, churches, businesses, and other community needs.

The current mulnipurpose work conducted at LANL reflects DOE's major program activities that include Defense Programs, Nuclear Nonproliferation, Energy Research, and Environmental Mamgement missions. LANL activities focus on technology research and development, education and training, technology transfer for DOE and others, environmental restoration, waste management, and the nation's nuclear weapons stockpile stewardship and management support. Some tracts of land have been recognized by DOE and LANL as nonessential to meet LANL's current and foreseeable programmatic missions. These tracts of land may be disposed of by 2 transfer of government ownership provided there is reason to believe that the land is unlikely to be required for DOE use.

DOE has recently reviewed its responsibility to further the self-sufficiencies of the Atomic Energy Communiries, including Los Alamos, in the face of increasing budgetary constraints and pressures, together with the downsizing or closure of some of the facilities within the nuclear weapons complex. Various potential means for mitigating the reduction or removal of monetary support from the agencies or municipalities the nation currently provides with yearly stipends have come under consideration. As stated in the closing chapters of the AECA of 1955, as amended, " ... the Administrator shall assure that the governmental or other entities receiving assistance hereunder utilize all reasonable, available means to achieve financial self-sufficiency to the end that assistance payments by the Administrator may be reduced or terminated at the earliest practical time." In spite of all effors to the contrary, the transfer and self-sufficiency process has been slower for Los Alamos than for other Atomic Energy Comraunities due to its unique nature and location. Proposed termination of certain assistance payments for the County will occur in July 1997. DOE regards this transfer of land as being intertwined with both the issues of county self-sufficiency and the elimination of funding for assistance payments.

\subsection{Purpose of and Need for DOE Action}

DOE is responsible for providing support to the County as an Atomic Energy Community, under authority of the AECA of 1955 (42 \$2301-2394), as amended, while being obligated to facilitate the fartherance of County self-sufficiency. The current subsidy funding to the County is in the amount of 2.6 million dollars per year; the loss of these Federal funds is scheduled to occur by July 1997. The AEA of 1954, as amended, provides authority to DOE for the transfer of property to the County by authorizing DOE to sell, lease, grant, and dispose of real property as necessary to carry out the missions directed by the AEA (42 U.S.C. Section 2201(g)). DOE needs to assist the County in its effort to become self-sufficient by providing for a means by which it can offset the scheduled elimination af certoin DOE ctipend ondring from recent Congressional actions. DOE can meet this need while meeting its legal obligations to effect the timely transfer of property to the County also for the purpose of encouraging self-sufficiency. DOE is of the opinion that the health and well-being of 
LANL is inexplicably tied to the continued health, well-being, and longevity of the County commnnities. To this end, there are two aspects to the self-sufficiency of the County: one pertains to the viability of the County itself, and another relates to the viability of DOE and LANL via the County. Without a healthy local economy and a community to service LANL needs and enhance LANL's ability to recruit and retain qualified scientific and technical staff, the continued function of LANL to meet critical national missions would be compromised.

To meet its purpose and need for action in a timely fashion as a part of its fulfillment of support responsibilities and obligations focused at aiding in the self-sufficiency of the County, DOE proposes to transfer ownership of the DP Road property for future business park or light industrial development purposes. The Proposed Action is intended to accelerate economic development activities within the County by creating regional employment opportunities through offering underutilized Federal land for private sector use. Economic development for the County would be supplemented by the opportunities offered through the attainment of additional property ownership and its subsequent use in the case of the proposed land transfer of the DP Road tract as well. The transfer of ownership is ripe for DOE decision at this time because the County has identified not only possible future uses of the land tract, but has had some strong indications of interest from the private sector corporations for development within the County.

\subsection{Scope of This EA}

A "sliding-scale" approach is the basis for the arralysis of potential effects in this EA. That is, certain aspects of implementation of the Proposed Action have a greater potential for creating adverse environmental effects than others; therefore, they are discussed in greater detail in this EA than those aspects of the action that have little potential for effects. For example, implementation of the Proposed Action could slightly increase the net atmospheric emissions from land development activities, which could in turn result in a negligible effect on local air quality. The EA, therefore, presents descriptive information on air quality only to the extent necessary for effects analysis, and not for the entire County.

When details about a Proposed Action are incomplete, as they are for implementation of the Proposed Action evaluated in this EA (that is, for example, the exact future use of the land is unknown at this time), 2 "bounding" analysis is often used to assess potential effects. When this approach is used, reasonable maximum assumptions are made regarding emissions, effluents, waste streams, and project activities (see Sections $2.0,4.0$, and 5.0 of the EA). Such an analysis usually provides an overestimation or health protective representation of potential effects. In addition, any future actions that exceed the assumptions ("bounds") of the effects analysis would be considered unacceptable, and additional NEPA review would be required.

\subsection{Public Involvement}

DOE provided written notification of its intent to conduct this NEPA review to the State of New Mexico, the four Accord Tribes, and to over 30 known stakeholders in the County area. The Predecisional Draft EA was issued on November 15, 1996. It was provided to the State and the four Accord Tribes for review and comment at the same time that it was made available to the public for review through placement in the DOE Public Reading Rooms in Los Alamos and Albuquerque. Upon request, the Predecisional Draft EA was provided to all interested parties for their review. The 
Predecisional Draft EA was also available for public review through the World Wide Web Computer Internet System (hup://lib-www.lanl.gov).

In response to stakeholder requests, the comment period on the EA was extended to January 3, 1997. DOE received six comment letters on the Predecisional Draft EA and provided individual replies to each commentor. Where appropriate, changes were made to clarify or correct the Final EA. 
This Page Intentionally Left Blank 


\subsection{DESCRIPTION OF THE PROPOSED ACTION AND ALTERNATIVES}

This section describes the Proposed Action, together with the further proposed property use after implementation of the Proposed Action, and discusses alternatives considered for enabling DOE to meet its purpose and need for agency action. The No Action Alternative is analyzed in Section 2.2 as a baseline to compare with the consequences of implementing the Proposed Action and the resulting subsequent land use. Alternatives that were considered but were not analyzed further in this EA are discussed in Secrion 2.3.

\section{Descripition of the Proposed Action}

DOE proposes to transfer ownership of a 12 hectare $(28$ acre) tract of land located along DP Road, which is currently part of LANL's TA-21, to the County of Los Alamos. This land was acquired through purchase in 1943 by the Federal government. Prior to Federal ownership, this land in its entirety was the property of the Los Alamos Ranch School. The transfer of this tract would result in a permanent change to the existing DOE property boundaries for TA-21. Subsequent to implementing the Proposed Action, the County would develop the tract of vacant land for use as a business park or for light industrial use. The County specifically proposes to develop the property within the foreseeable future ( 5 to 10 years) for their own use with the construction of a new office building(s) to house County employees, and the construction of new warehouses, garages, and support buildings for the transfer of its equipment maintenance, school bus yard (including fuel services), and school supplies warehousing activities to the site. Alternatively, the County may pursue another course of action that would result in the same type of land use, namely, they may convey the tract of land to other parties for development and use as a commercial or professional business park, or for light industrial business purposes (Appendix A).

\subsection{Location and Description of the DP Road Tract}

The general location of the DP Road tract within Los Alamos County is shown on Figure 1-2. The specific area being considered for transfer is highlighted on Figure 2-1. The tract is bounded by a publicly accessible road, DP Road, and other portions of TA-21 land along its northern boundary. Along its southern and eastern borders lie additional TA-21 lands that include portions of Los Alamos Canyon. The western side of the DP Road tract is bordered by a mixture of commercial business and County-owned properties, together with a small portion of TA-21 land. The DP Road tract is Federal land and, as such, is not subject to land use controls by the County, but is designated as "Federal Iands or FL" for County planning purposes. The non-Federal land surrounding the tract is zoned C-3 (LA County 1994). This designation allows for heavy commercial development; detailed information regarding zoning designations is provided later in this document in Sections 3.4 and 4.1.2.

The tract is currently vacant land covered by native vegetation and is closed to public access by DOE security fencing. The tract has been previously disturbed by surface activities and by prior site facilities or structures. There are no aboveground structures located on the land tract. Unimproved (dirt) roads cross the land track. Buried utilities are present at the site, including a sewer main and a potable water main. The sewer main bisocer the crect from the east to west, and a portion of the line crosses from north to south over the land tract. There are seven sewer access holes located along the sewer main scattered throughout the tract (County Utility Maps). The water main runs parallel with 


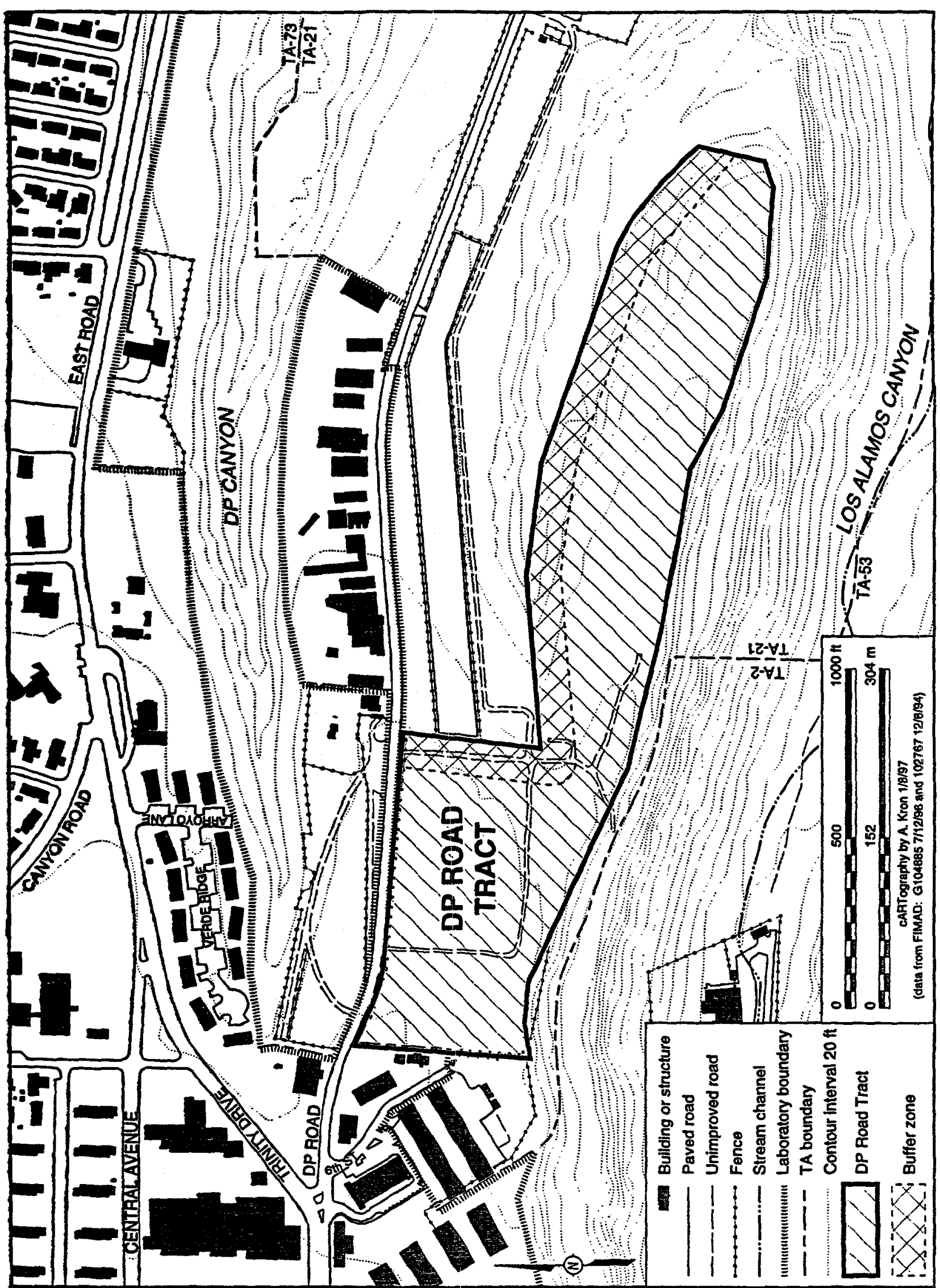

Figure 2-1. Proposed DP Road Tract. 
DP Road and the western boundary of the tract. There are six fire hydrants present over the tract, although they are not currently connected to the water main. A buried radioactive liquid waste line that is currently in use also crosses the land tract. This waste line is a $7.5 \mathrm{~cm}$ (3.0 in.) diameter pressurized line that is buried to 2 depth of approximately 1.0 to $1.5 \mathrm{~m}$ ( 3 to $5 \mathrm{ft}$ ). This waste line transports radioactive liquid waste from TA-21, across the DP Road tract, through Los Alamos Canyon, and ultimately to the Radioactive Liquid Waste Treatment Facility at LANL's TA-50. Two sites on the land tract are areas of concern for suspected contamination. These sites have been designated as Solid Waste Management Units (SWMUs) or Potential Release Sites (PRSs), and are associated with past use of the land tract by LANL operations. Both sites have undergone contaminant investigations. One site was determined to not have been associated with potentially hazardous materials and DOE has concluded that no future site clean-up actions are required (a request for permit modification has been made to the appropriate regulators). The other site, a septic leach field, was cleaned up and DOE has determined that no further action is required. Both sites are believed to be sufficiently free of hazardous contaminants that they pose no potential health threat and nnrestricted future land use would be appropriate. Right of reentry would be maintained by DOE for both sites pending completion of regulatory approval for release. An adjacent parcel of land is the site of a material disposition area PRS the has not been fully characterized for lateral extent. A buffer zone of $30 \mathrm{~m}$ (100 ft) from the property boundary around that PRS would be established and maintained as long as necessary to complete characterization.

\subsubsection{Proposed DP Road Tract Uses}

The ownership of the DP Road tract would be transferred by the DOE to the County, which could retain ownership or convey all or part of it to a third party. The County has indicated that its preferred use of the land tract would be to develop the property within the foreseeable future ( 5 to 10 years) for their own use with the construction of a new office building(s) to house County employees, paved parking areas, and new warehouses, garages, and support buildings for the transfer of the school bus yard (including fueling facilities), equipment maintenance, and school supply warehousing activities to the site. Alternatively, the County may pursue another course of action within the foreseeable future that would result in the same type of land use, namely, they may convey the tract of land to other parties for development and use as a commercial or professional business park, or for light industrial business purposes.

The proposed County land use zoning for the DP Road tract could be one or more of the following in keeping with the use of the current zoning of the nearby townsite area: light commercial and professional (C-1), civic center business and professional (C-2), heavy commercial (C-3), and light industrial (M-1). No residential use would be anticipated for the land tract. The use of the land tract for future residential-type purposes would be temporarily limited by DOE such that as long as LANL's TA-21 remains operational (which is expected to continue for the foreseeable future), no residential-type ${ }^{1}$ use of the land tract would be permitted. Additionally, a right-of-way or easement would be established through the deed transfer process so that DOE would retain use of the buried

The term "residential use" is intended to include such possible uses as: high-density multi-family dwellings (e.g., apartments, condominiums, or town homes), single-family, dwellings, motels, hotels, hospitals, nursing homes, child-care centers, and half-way houses. 
Iadioactive liquid waste line that crosses the land tract together with site re-entry rights for the performance of possible monitoring, repairs, maintenance activities, replacement or removal of the line when it is no longer needed. DOE would retain the right to re-enter the property for the purpose of taking further action related to the two designated PRSs. Each PRS would be fenced and inaccessible for development until it is determined by DOE that each site can be released for unrestricted use. DOE and LANL would continue to be responsible for environmental restoration activities related to past or current LANL use of the DP Road tract. All mandated environmental restoration activities at SWMUs or PRSs would be performed with the approval of the Environmental Protection Agency (EPA) and the New Mexico Environment Department (NMED). The implementation of any controls regarding the type, extent, and intensity of development imposed on the transferred tract by DOE or by County land use zoning designations or lot development requirements would be the responsibility of the County. Under the Proposed Action and subsequent land use by the County, LANL would continue standard environmental protection procedures on DOE and LANL controlled land surrounding the proposed DP Road tract. Any environmental monitoring and protection on the DP Road tract, if necessary, would be the responsibility of the County.

All tract improvements, including utilities, roads, and new construction and support services, would be the responsibility of the County or of a third party. Structures built on the tract would be constructed in accordance with applicable County construction codes and zoning ordinances. Development of the site could involve common construction activities such as ground clearing, excavation, foundation laying, erection, and finishing work for buildings and paved parking areas. As much as 12 hectares $(28$ acres) of soil could be moved or disturbed for construction activities. Best Management Practices (BMPs) for soil and silt retention would be employed during construction. Development and construction activities on the tract could occur concurrently or in phases. Development of the tract would be expected to be complete within a ten year time frame. Buildings would be no higher than $15 \mathrm{~m}(50 \mathrm{ft})$ above ground level, per County building restrictions. In order to adequately bound the analysis of the proposed future site use with regards to estimating a maximum number of site workers, it is assumed that at least three professional office buildings could be constructed on site; each building would be about $2,780 \mathrm{~m}^{2}\left(30,000 \mathrm{ft}^{2}\right)$. The number of new employees expected to occupy the tract from this use could range as high as 450 . If the County relocates certain of its operations to the tract, about 100 current County employees could be moved from their current County workplaces. Development would not require installation of any new major site utilities, only tie-ins to the existing infrastructure present along the DP Road right-of-way. Wastes from construction activities would be expected to be nonhazardous and could be disposed of in the County landfill Construction materials would be procured primarily from local New Mexico suppliers. Construction workers would be drawn from local communities and communities across the State of New Mexico.

All site activities would be conducted in accordance with the County codes and ordinances, and applicable state and Federal laws and regulations. Additional bounding analysis assumptions for future site use limits future tenants or owners to only performing some low-hazard activities at the tract such as heavy machinery or equipment repairs, and to testing of electronic components or routine laboratory activities. Minimal emissions of hazardous air pollutants and minimal amounts of hazardous wastes could be generated by routine operations. Any air emissions or generation of hazardous wastes would be regulated by the State of New Mexico. No wastewater effluent would be 
discharged to the environment without passing through National Pollutant Discharge Elimination System (NPDES)-permitted outfalls. Industrial wastewater effluent may require pretreatment at the site to meet County water treatment facility acceptance criteria before being discharged into the Coumy sewer collection system. Stormwater from the tract could be retained on-site in a constructed evaporative retention pond, discharged from a central site collection point, or allowed to sheet flow into Los Alamos Canyon. Sanitary wastewater would be routed to and treated at existing sewage treatment facilities owned and operated by the County in accordance with Federal and state regulations. With 450 site employees, about 49,205 liters (13,000 gallons) of sanitary wastewater would be generated per day. Solid wastes generated from activities at the land tract would be disposed of at the existing County tandfil and regulated by the County and the State of New Mexico. With a maximum of 450 employees, annual solid waste generation during site occupancy would be estimated to be about $2,700 \mathrm{~m}^{3}\left(3,600 \mathrm{yd}^{3}\right)$.

\section{No Action Alternative}

The No Action alternative provides an environmental baseline to compare to the potential effects of the Proposed Action. It me considered even if DOE is under a court order or legislative command to act [10 CFR 1021.321(c)]. Under the No Action alternative, the DP Road tract would remain under DOE control and would not be transferred to the County. The tract could remain undeveloped or could be developed in the future by DOE for some as yet undetermined use. Potential effects associated with the development and use of this tract of Federal land as planned by the County would not occur. A total of about 12 hectares ( 28 acres) of previously disturbed but undeveloped Federal land would continue to act as a buffer between LANL and the community of Los Alamos. The potential economic benefits to the County from the development of this tract would not occur. Without economic development, the County would need to seek other alternatives to offset the loss of certain Federal subsidies in 1997.

Since the implementation of this alternative would not enable DOE to transfer currently available land to the County that could be used for the common good of the public and to mitigate the loss of Federal funds, the No Action alternative does not meet DOE's purpose and need for action. However, consistent with the CEQ and DOE NEPA regulations (40 CFR 1500 and 10 CFR 1021 , respectively), this alternative is analyzed for comparison of potential effects with those of the Proposed Acrion in this EA.

\subsection{Alternatives Considered But Dismissed from Further Consideration}

Three alternatives were considered but have been dismissed from detailed analysis: (1) the sale of the land tract to a nongovernment buyer, (2) the transfer of the land tract to another Federal agency or Indian tribe, and (3) the lease of the land tract. Under Alternative 1, the sale of the land to 2 nongovernment buyer would require that the land tract be declared "excess" real property and that it be transferred from DOE to the General Services Administration (GSA) for disposal. The DP Road tract has not been determined to be excess real property; declaring it so and disposing of it through the GSA would not meet the purpose and need for DOE action with respect to DOE's responsibilities and liabilivies to the County ser forth in the AEA and AECA. Alternative 2, the transfer of the land tract to another Federal agency or Indian tribe, is also not consistent with DOE's purpose and need with respect to meeting DOE's responsibilities and liabilities to the County regarding the AEA and the 
AECA. Neither alternative 1 nor 2 have the prospect of immediacy in achieving the goal of enhancing County self-sufficiency particularly in light of the impending elimination of County subsidy payments in July 1997. Alternative 3, the lease of the DP. Road tract to the County, would meet DOE's purpose and need for action, but is not considered a reasonable alternative. The lease of land to an entity other than the County would not allow DOE to meet its purpose and need for action. Since there is no known long-term future DOE need for the DP Road tract, the permanent transfer of that property is a reasonable action and the temporary lease of the land tract is not. For these stated reasons, these alternatives were dismissed from detailed consideration and further analysis in this EA. 


\subsection{AFFECTED ENVIRONMENT}

Section 3.0 describes the natural and human environment that could be affected by implementing either the Propesed Action or No Action alternative. Environmental issues not likely to be affected are not addressed in detail. Detailed descriptions of LANL's physical and socioeconomic environment, its climate, meteorology, hydrology, cultural resources, waste management, floodplains, wethands, and threatened and endangered species are presented in the 1979 Final Environmental Impact Statement for Los Alamos Scientific Laboratory Site (DOE 1979) and the most recent Environmental Surveillance Reports (LANL 1996).

\subsection{Regional Setting}

LANL is a government-owned, contractor-operated multidisciplinary research facility that is located on $111 \mathrm{~km}^{2}$ (43 mi') of land in north-central New Mexico approximately $100 \mathrm{~km}$ (60 mi) north of Albuquerque. It comprises a significant portion of Los Alamos County and extends into Santa Fe County-

Commercial and residemial development in the County is confined primarily to several mesa tops lying north of the core LANL facility, in the case of the Townsite, or southeast, in the case of White Rock and Pajarito Acres communities. The lands surrounding the County are largely undeveloped wooded areas with large tracts located to the north, west, and south of LANL administered by the U.S. Forest Service (Santa Fe National Forest), the National Park Service (Bandelier National Monument), and the Bureau of Land Management (to the east). The San Ildefonso Pueblo borders LANL to the east. The industrially developed acreage at LANL consists of approximately 30 active TAs.

Recreational resources such as hiking trails, parks, and athletic facilities are abundant in the County. Recreational opportunities such as camping, fishing, and hunting (U.S. Forest Service lands) are available on the surrounding Federal lands. In 1977, the U.S. Energy Research and Development Administration designated LANL as a National Environmental Research Park, which is used by the national scientific community as an outdoor laboratory to study the effects of human activities on the Southwest woodland ecosystems existing at the site.

Five publichy accessible vehicle routes convey traffic to and from LANL. State Road 502 (Main Hill Road) is heavily used by rommuter traffic from Santa Fe and Española. State Roads 4 and 501 provide access to LANL from small communities located to the west of LANL. East Jemez Road and Pajarito Road are DOE-owned and provide public access to many of the TAs at LANL. In addition to private vehicles, DOE and LANL employee and government vehicles contribute extensively to the volume of traffic on each of these roadways

The DP Road tract is located on a mesa about $2,165 \mathrm{~m}(7,100 \mathrm{ft})$ above sea level and bordered to the south by Los Alamos Cemyon. The climate is typical of the Pajarito Plateau in having four distinct seasons and is characterizod es semi-arid temperate montane. Precipitation occurs primarily during the summer and winter seasons. The deep eanyon topagraphy combined with the forested slopes create irregular wind patterns on the mesas and in the canyons. Different wind intensities and directions may occur on the meses and in the canyons due to variable air temperatures. 
The Coumy's climate is characterized by seasonable, variable rainfall with precipitation rates ranging from 25 to $51 \mathrm{~cm}$ (10 to $20 \mathrm{in}$.) per year. Average minimum and maximum temperatures, based on 19- and 15-year means for the community of Los Alamos, have dropped as low as $-28^{\circ} \mathrm{C}\left(-18^{\circ} \mathrm{F}\right)$ and have reached as high as $35^{\circ} \mathrm{C}\left(95^{\circ} \mathrm{F}\right)$. The average mean annual precipitation rate for Los Alamos from 1961 to 1990 was approximately $48 \mathrm{~cm}$ (19 in.).

\subsection{Potential Environmental Issues}

Based on the description of the Proposed Action, potential environmental resources that may be affected as a result of implementing the action have been considered. Environmental issues were identified and either addressed or not analyzed, depending upon their individual applicability to the vicinity of the Proposed Action. Table 3.1 identifies the subsection where potential environmental issues are discussed or notes why they are not addressed in this document.

Table 3.1 Potential Environmental Issues

\begin{tabular}{|c|c|c|}
\hline 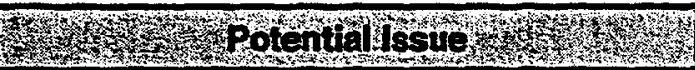 & 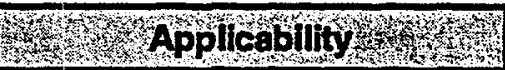 & Dessodbed hsector \\
\hline Socioeconomics & Yes & Section 3.3 \\
\hline Land Use/Traffic & Yes & Section 3.4 \\
\hline Ecological Resources $W$ etlands & Yes & Section 3.5 \\
\hline Waste Management/Environmental Restoration & Yes & Section 3.6 \\
\hline Aesthetics & Yes & Section 3.7 \\
\hline Human Health & Yes & Section 3.8 \\
\hline Air Quality & Yes & Section 3.9 \\
\hline Surface Water & Yes & Section 3.10 \\
\hline Noise & Yes & Section 3.11 \\
\hline Cultural Resources & NA-none present & Section 3.12 \\
\hline Environmental Justice & NA-none affected & Section 3.13 \\
\hline $\begin{array}{l}\text { National Resources: } \\
\text { Parks, forests, conservation areas, or areas of } \\
\text { importance for public recreation }\end{array}$ & $\begin{array}{l}\text { NA-none present at LANL or in } \\
\text { proximity to affected tract }\end{array}$ & NA \\
\hline Seismology and Geology & $\begin{array}{l}\text { NA-not applicable, buildings } \\
\text { would meet current seismic codes }\end{array}$ & NA \\
\hline Wild Horses and Burros & NA-none present & NA \\
\hline Prime Farmland & NA-none present & NA \\
\hline Coral Reefs and Tundra & NA-none present & NA \\
\hline Ground Water & NA-none affected & NA \\
\hline
\end{tabular}

\subsection{Socioeconomic Conditions}

Los Alamos County has an estimated population of 18,115 (U.S. Census, 1990, projected to 1995 [Commerce 1991D. Statistics for population, housing, and public infrastructure are based on the region of influence (ROI), a three-county area in which more than 90 percent of LANL employees reside. The ROI includes the counties of Los Alamos (with 48.3 percent of LANL employees), Rio Arriba ( 20.8 percent), and Santa Fe (19.0 percent). The ROI experienced steady population growth between 1980 and 1990, with a 1990 total of abour 150,000 persons. By the year 2000, population in the ROI is expected to be approximately 169,000 persons (BEA 1995; Commerce 1994; ULI 1995). 
The ROI includes the Santa Fe Metropolitan Statistical area. Between 1988 and 1995, employment in the ROI was projected to increase from 66,800 to 75,900. The Bureau of Economic Analysis (1990) projects a compounded annual average growth rate in employment of 1.26 percent from 1995 to 2003 ( 8,018 jobs). In 1995, LANL employed approximately 6,200 persons accounting for 10.8 percent of employment in the area. Unemployment in the ROI has consistently been about 6.2 percent.

Housing prices have dropped recently due to out-migration resulting from LANL layoffs. Currently, the County has approximately 135 vacant housing units and 40 vacant rental units. The number of vacant housing units in the ROI increased from approximately 4,385 units in 1980 to about 6,845 units in 1990. In the year 2000 there will be about 9,300 total vacant units if current trends continue.

The County is responsible for residential and commercial distribution of gas, water, electricity, and sanitary sewer services to the community on the north side of Los Alamos Canyon Bridge. DOE owns and operates all utilities on the south side of Los Alamos Canyon Bridge. DOE also owns and mainzains several main distribution lines located throughout residential and commercial areas on the north side of Los Alamos Canyon Bridge. The County is allowed to "tap into" these main distribution lines at a number of points of delivery. The County's use of electricity, water, and natural gas from July 1995 to June 1996 was 7,778,344 kilowatt hours of electricity; 71,778 million cubic feet of natural gas; and 96,963 thousand gallons of water.

Table 3.3.1 shows the levels of police and fire protection, health care services, and per pupil expenditures on education for the counties that comprise the ROI. In the County, approximately 3,500 students were enrolled in public schools in 1995 (19.3 percent of the County's population), the ratio of uniformed police officers to residents is currently 1 to 489 , and the ratio of uniformed fire men to residents is 1 to 226.

Table 3.3.1 Public Services

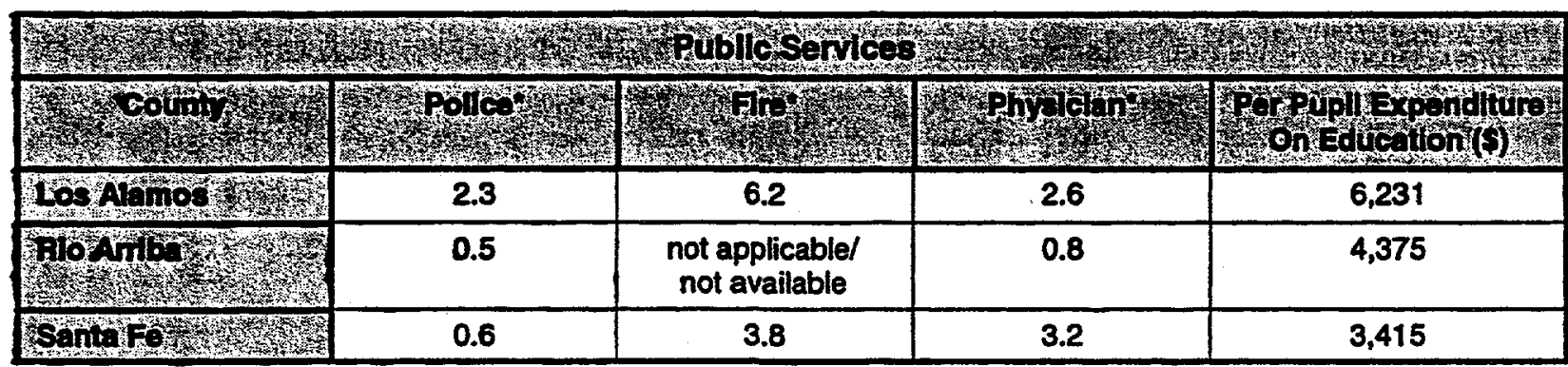

- Number of service personnel per 1,000 population

Soumere Los Alamos County (1995); New Mexico Public Schools (1994); American Medical Association (1994); City of Espanola Police Department (1995); Rio Arriba County Sheriffs Department (1995); City of Santa Fe Police Department (1995); Santa Fe County Sherifts Department (1995); Rio Arriba County Payroll Department (1995); City of Santa Fe (1995); City of Espanola (1995); Los Alamos County Police and Sheriffs Department (1995).

Most of the revenue generated by the County (approximately 18.7 million dollars) can be broken down as follows: Approximately 40 percent of the revenue comes from gross receipts tax, 20 percent from property taxes, 15 percent from DOE assistance payments (2.6 million dollars), and about 5 percent from utilities. The remaining 20 percent comes from miscellaneous fines and fees. In connection with the end of the annual assistance payments under the AECA, the County will receive 
2 hump sum payment of about 22.6 million dollars. The County is expecting this lump sum payment sometime around January 1997. In October 1996, the President signed the Energy and Water Development Appropriations Act of 1997 authorizing the lump sum payment.

The DP tract is currently undeveloped and offers no employment or revenue opportunities. The 12. hectare (28 acre) tract is not used for any social or economic purposes. In general, there is an adequate amount of servicing infrastructure to support tract development.

\subsection{Land Use and Traffic Volumes}

The DP Road tract totals approximately 12 hectares ( 28 acres). The tract is bounded by a publicly accessible road, DP Road, and other TA-21 land along its northern boundary. Along its southern and eastern borders lie additional TA-21 land, including Los Alamos Canyon. The western side of DP Road is bordered by 2 mixture of commercial land and County owned properties together with a small portion of TA-21 land. The current zoning of private property at DP Road is C-3, which is designated for heavy commercial district use. The heavy commercial district is intended to accommodate commencial uses allowed in the $\mathrm{C}-1$ and $\mathrm{C}-2$ districts and those which generate more traffic and noise. Included are automotive-connected uses such as service stations, repair garages, tire shops, motels and hotels, uses such as large stores, drive-in or take-out facilities and commercial recreation establishments.

Access to the DP Road tract is from DP Road. "The intersection of DP Road with Trinity Drive just west of the DP Road tract is heavily used and is often congested. Between 7,000 and 8,000 vehicles travel along the segment of Trinity Drive where it intersects with DP Road each day.

\subsection{Ecological Resources/Wetlands}

The soils in the proposed transfer tract consist mostly of ruff rock outcrop with developed Tocal soils (Nyhan et al. 1978). Because this is a disturbed area, engineering fill gravels and sands and nonnative fill soils may be present at the DP Road tract. This tract is moderately vegetated with native grasses, herbs, shrubs, and small trees. There are stands of Gambel's oak (Quercus gambelii Nutt.), Russian olive trees (Elaeagnus angustifolia L.), one-seed juniper (Juniperus monosperma [Engelm.] Sarg.), elm trees (Ulmus sp. I), and ponderosa pine (Pinus ponderosa Laws.).

In the disturbed areas of the DP land tract, the understory is comprised of various grasses such as western grass (Agropyron smitbii Rydb.), Canada bluegrass (Poa compressa L.), bottlebrush squirreltail (Sitanion bystrix [Nutt.] J.S. Smith), cheat grass (Bromus tectorum L.), sand dropseed (Sporobolus cryptandrus (Torr.) Gray), and a variety of herbs such as summer cypress (Kocbia scoparia L.), prickly letruce (Lactuca spp. L), and horseweed (Conyza canadensis L.). Surveys of the habitat at this tract indicated one major plant community on the mesa and in the surrounding canyons. The ponderosa pine plant community at this tract area consists of as many as 159 plant species, 76 nesting bird species, 26 mammal species (including 10 bat species), and 9 reptile and amphibian species. This area may also be heavily used as a foraging area, wintering area, and migratory route for large game species such as mule deer (Odocoileus bemionus) and elk (Cervus elaphus).

A list of threatened, endangered, or sensitive (TES) species of concern potentially occurring on or in the vicinity of the tract was compiled using field survey data to identify potential TES habitats. The 
current status of Federally listed threatened or endangered species protected under the Endangered Species Act of 1973 (as amended) on this list were confirmed by comparing it to a recently furnished species list from the U.S. Fish and Wildlife Service (August and October 1996). Based on habitat requirements for each TES species on the Pajarito Plateau, all but the peregrine falcon (Falco peregrinus) [Federally endangered species], spotted bat (Euderma maculatum) [species of concern], and Mexican spotted owl (Strix occidentalis lucida) [Federally threatened species] were dismissed from further consideration for the DP Road tract. Further examination of existing plant transects and multiple year surveys for these three potential species in the area surrounding this tract indicated the absence of these species and their critical habitats. Therefore, no further surveys are planned for the DP Road ract by the DOE

No wetlands or floodplains were identified from the US Fish and Wildlife Service (USFWS) National Wetland Inventory (NWI) Maps within the boundaries of the DP Road tract. However, within adjacent Los Alamos Canyon there are stretches of riverine and palustrine wetlands. A narrow floodplain exists within Los Alamos Canyon. Los Alamos and DP Canyons contain ephemeral streams that flow primarily in the summer months.

\subsection{Waste Management and Environmental Restoration}

\section{Waste Managememt}

Ios Alamos County has established procedures to be in compliance with applicable laws and regulations for collecting, processing, and disposing of municipal solid waste. Trash from commercial companies is collected in County trucks on a regular basis and also on a special request basis and disposed of at the County landfill. In 1995, about $16,100 \mathrm{~m}^{3}\left(21,100 \mathrm{yd}^{3}\right)$ of commercial trash was disposed of at the County landfill. Rubble from LANL, the County, contractors, and individuals is accepted at the County landfill and is used to fill in a location that is intended to become a road in the future. In 1995, 10,600 metric tons (11,700 tons) of rubble were disposed of at this location. The County also maintains a separate location at the landfill for construction debris which is available for re-use by individuals or companies. In 1995, about 3,890 metric tons ( 4,290 tons) of construction debris were disposed of at the County landfill. Another location within the County landfill is used to process green waste such as tree limbs, brush, leaves, and grass. This material is shredded and some of it is composted on-site. The processed materials are available to the public, schools, County, and LANL for use as a ground cover or soil amendment. About $10,500 \mathrm{~m}^{3}\left(13,800 \mathrm{yd}^{3}\right)$ of green waste were disposed of at the County landfill in 1995 (LA County 1995). LANL's solid waste is disposed of at the County landfill. LANL disposes of an average of about $23,910 \mathrm{~m}^{3}\left(31,270 \mathrm{yd}^{3}\right)$ annually at the County badfill (DOE 1996). This landfill has an expected use life of about 15 more years.

The County operates two sanitary wastewater treatment facilities, one in White Rock and one in Bayo Canyon near Los Alamos Townsite. There are seasonal variations but on the average, approximately 350,000 gallons per day are processed at the White Rock facility. Approximately 1,000,000 gallons per day are processed at the Bayo Canyon facility. Neither plant is operating at full capacity but there are conswaints at other parts of the sanitary wastewater system that limit the maximum amount they could process. Nearly all of the sanitary wastewater generated at LANL goes to the LANL Sanitary Wastewater Systems Consolidation (SWSC) plant at TA-46. The SWSC plant processes approximately 250,000 gallons per day. 


\section{Environmental Restoration}

The envirommental restoration (ER) program at LANL is actively involved in characterizing and cleaning up former waste sites. SWMUs and PRSs located on Federal lands at LANL are in various stages of clean-up pending either additional LANL activities or U.S. EPA concurrence with DOE's recommendation of no further action. The DP Road tract has two sites of suspected contamination or areas of concern. These suspect sites are known as PRSs and generally had their origins during the early years of LANL operations. The identified PRSs on these land tracts are listed and described below. PRS 21-015 is located near the northern boundary of the DP Road tract. Since the extent of remediation, if any, for PRS 21-015 has not yet: been determined, a buffer zone of $30 \mathrm{~m}$ (100 ft) will be maintained along the eastern and northern boundaries of the DP Road tract to prohibit construction in proximity to this PRS. The PRSs locations are shown on Figure 3-1.

- PRS D-O1D(a) was a suspected surface disposal area. This site was investigated when a 1948 aerial photograph showed what appeared to be excavated trenches. Photogrammetric analysis showed stockpiles of supplies, not trenches, of stored 55 gallon drums. It was concluded that this site was not associated with potentially hazardous materials. It has been recommended to the EPA and the State that no further action be taken at this site (Request for Permit Modification 1995).

- PRS D-O3O(b) is a septic system and leach field that served former warehouses, two office buildings, and a cold storage plant in the early operational days of LANL. Available information indicates that the septic system handled only sanitary waste. The septic tanks at this site were cleaned up through a LANL initiated Voluntary Corrective Action (VCA). No further action has been taken (Hartman 1996).

Several PRSs are located in Los Alamos Canyon upstream from the DP Road tract. No PRSs are located in Los Alamos Canyon downstream from the DP Road tract; however, radionuclides are present downstream from the DP Road tract. The ER program is currently sampling and characterizing these areas. Sediment sampling in Los Alamos Canyon downstream from the DP Road tract has shown the presence of plutonium, americium, cesium, strontium, and tritium either at trace levels or at levels elevated slightly above background (ESR 1996).

\subsection{Aesthetics}

The DP Tract is a previously disturbed but undeveloped area. The portion of the tract bordering DP Road (about $305 \mathrm{~m}$ or 1,000 ft) has moderate coverage of mature hardwood trees and an understory of grasses and weedy annuals and perennials. This portion lies near existing commercial or industrial areas and other undeveloped areas. The southern portion of the tract contains ponderosa pine and open grassy or shrubby areas. A short trail crosses the DP Road tract and provides access from DP Road to the Los Alamos Ranch Trail, which runs along the north side of Los Alamos Canyon. This trail is occasionally used by transient foot traffic. The taller trees along DP Road obscure the view of some of the lower peaks of the Sangre de Cristo Mountains to the southeast, but the mountains are clearty seen directly ahead while driving east down DP Road. A portion of the east flank of the Jemez Mountains is visible while driving west down DP Road. The predominant characteristic of the area is industrial and commercial except to the south and east where the canyons are largely undeveloped and covered by native vegetation. The project area is visible from adjacent commercial or industrial areas 


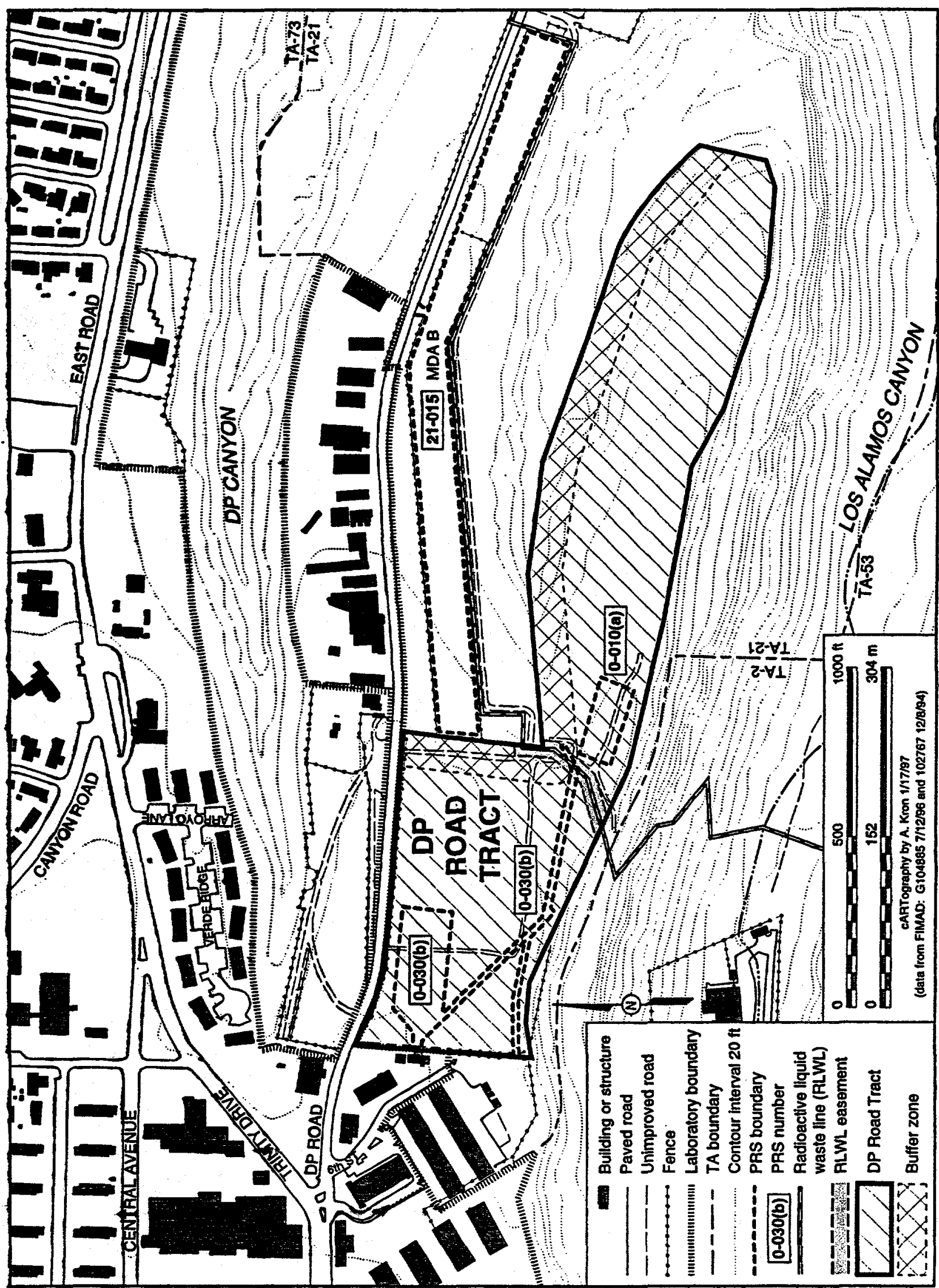

Figure 3-1. Locations of environmental restoration sites on the DP Road Tract. 
along DP Road. The most likely groups to view the DP Tract are LANL workers driving to TA-21, workers at businesses along DP Road, and local residents patronizing those businesses.

\subsection{Human Health}

There are no potential sources for human exposure to radioactive, chemical, or physical hazards located on the DP Road tract. The PRSs at the DP Road tract pose no imminent human health threat. The greatest human health threat from use of the DP Road tract area is in the form of a physical or biological (e.g., animal bite) hazard. The daily use of the area by automobiles and pedestrians poses a potential human health hazard.

The radiation environment at LANL and the surrounding communities is continuously monitored and characterized. The results are reported in annual LANL environmental surveillance reports (LANL 1996). Air emissions are routinely sampled at locations on LANL property, along the DOE boundary perimeter, and in more distant areas that serve as regional background stations.

Atmospheric concentrations of radioactive nuclides (radionuclides) are measured to estimate internal radiation doses. Thermoluminescent dosimeters (TLDs) are used to determine external penetrating radiation doses in the area. Background dose estimates are subtracted from the measured values to determine the effective dose equivalents ${ }^{2}$ (EDE) to the public outside the site boundary and at the nearest residence. The maximum dose rate at the DP Road tract from routine LANL operations would be approximately 0.4 mrem per yr, assuming the Los Alamos Neutron Scattering Center and Energy Research Programs (LANSCE) facility is operating at full capacity. 'This estimated maximum annual dose rate was calculated using an EPA approved radiological air emissions computer modeling code (i.e., AIRDOSE).

From these data, estimates of the human risk of developing excess fatal cancers (i.e., cancer mortality above and beyond the background incidence rate of from 20 percent or 1 in 5) from the radiation environment are made based on currently accepted mathematical models (ICRP 1991) that estimate radiation risk. These risk estimates predict the chance, or probability, of excess cancer fatalities.

The radiation environment at LANL consists of both (1) natural background radiation and induced background levels of radioactivity in the surrounding communities, and (2) the worker's radiation environment within their work areas. All individuals are subject to some irradiation even though they may not work with radioactive substances. The annual average EDE from background and induced radiation for 1994 to nearby residents in Los Alamos and White Rock was 348 mrem and 336 mrem, respectively (LANL 1996). The average EDE attributable to 1994 LANL operations was $0.27 \mathrm{mrem}$ and 0.06 mrem for residents in Los Alamos and White Rock, respectively (LANL 1996). The maximum annual dose to a potentially exposed member of the public from 1994 LANL operations is estimated to be approximately 7.62 mrem per $y r$. The DOE's public dose limit is 100 mrem per yr EDE from all pathways. Table 3.8.1 summarizes the various estimated annual exposures to the public associated with IANL operations during 1994.

2 Effective dose equivalent is a term for the estimated radiation dose to the whole body that would result from a dose to any one or more body organs. 
Table 3.8.1 Summary of Annual Effective Dose Equivalents (EDE) for 1994

\begin{tabular}{|c|c|c|c|c|}
\hline (1) & 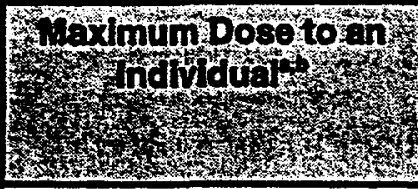 & 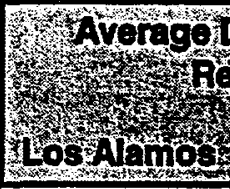 & 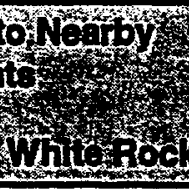 & Collowivosos \\
\hline 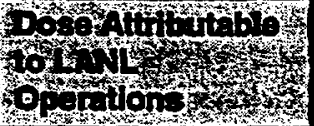 & $7.62 \mathrm{mrem}$ & 0.27 mrem & 0.06 mrem & 4 person-rem \\
\hline Bachorourd Dosol & 342 mrem & 342 mrem & 327 mrem & 77,000 person-rem \\
\hline
\end{tabular}

Waximum dose to an individual is the dose to any individual at or outside LANL where the highest dose rate occurs (2.e., business north of TA-53).

Doses ane reported at the $95 \%$ confidence level.

Source: (LANL 1996)

\subsection{Air Quality}

The irregular and complex terrain and rough forest surfaces in Los Alamos and surrounding areas affect atmospheric dispersion. The terrain and forests create an aerodynamically rough surface, forcing increased horizontal and vertical turbulence and other dispersion. The dispersion generally decreases at lower elevations where the terrain becomes smoother and less vegetated. The canyons surrounding IANL channel the air flow, which also limits dispersion. The frequent clear skies and light winds rypical of the summer season cause daytime vertical air dispersion.

IANI and the County are remote from major metropolitan areas and major sources of pollution. Air quality is better than ambient air quality standards set by EPA and NMED (LANL 1996). Radioactive and nonradioactive air emissions are in compliance with the Clean Air Act and the New Mexico Air Quality Control Act (LANL 1996).

LANL facilities at the TA-21 complex generate minor amounts of radioactive air emissions. The disused plutonium production facility at TA-21 is presently undergoing decontamination and decommissioning (D\&D). The facility's laboratory wings are being demolished and removed. Dust emissions are generated and monitored. The present tritium operations at TA-21 produce nominal radioactive air emissions. The Omega West Reactor (TA-2) in the bottom of the adjacent Los Alamos Canyon is no longer in operation. The reactor is expected to undergo D\&D in the near future. Some radioactive air emissions may be produced during the D\&D operations. There are no nonradiological air emissions generated at the DP Road tract due to the lack of facilities at the tract. There are no known chemical waste sites at the tract to contribute any air emissions. There are no large operations in the vicinity of the DP Road tract that routinely emit nonradiological air pollutants. Automobile exhaust from vehicles using DP Road is an emission source. DP Road, however, is only lightly Iraveled by automobiles.

\subsection{Surface Water}

Surface water a LANL is monitored and evaluated for compliance with the New Mexico General Stream Standards for Livestock and Wildlife Watering. The two monitoring stations along DP and Los Alamos Canyons have shown no excessive levels of metals or organics attributable to LANL operations. Los Alamos Canyon and DP Canyon received treated radioactive liquid waste in previous 
decades and some residual radioactivity has been found at the monitoring stations in these canyons. The levels of radioactivity in surface water are below the DOE derived concentration guides. (LANL 1996)

The Los Alamos Canyon watershed upstream from the DP Road tract comprises about $24.6 \mathrm{sq} \mathbf{k m}$ (9.5 sq mi) (based on McLin 1995). The DP Road tract contributes about 12 hectares (28 acres) to the Los Alamos Canyon watershed. An individual six-hour storm event with a probability of reoccurring once every two years, would produce a total runoff volume in Los Alamos Canyon in the vicinity of the DP Road uract of about 8 acre-feet, with a peak flow of about $19 \mathrm{cubic}$ feet/second.

\subsection{Noise}

Noise is defined as unwanted sound. Sound is a form of energy that travels as invisible pressure vibrations in various media, such as air. The auditory system of the human ear is specialized to sense the sound vibrations. Noise is categorized into two types: Steady-State Noise which is characterized as longer duration and lower intensity such as a running motor and Impulse or Impact Noise which is characterized by short duration and high intensity such as the detonation of high explosives.

The imensity of sound is measured in decibel (dB) units. In sound measurements relative to human auditory limits, the decibel scale is modified into an A-Weighted Frequency scale (dBA). The dBA is a scale of sound measurement that approximates the response of the normal human ear. The Aweighting reduces the contribution of lower frequency sound which is of less concern for human hearing conservation purposes. Thus, occupational noise exposures are measured in dBA.

Noise measured at LANL is primarily from occupational exposures. These measurements are taken indoors through the use of personal dosimeters and instruments. Occupational exposure data are compared against an established Occupational Exposure Limit (OEL). LANL defines the OEL administratively as noise to which a worker may be exposed for a specific work period without probable adverse effects on hearing acuity. The OEL for steady-state and impulse or impact noise at the Laboratory is based on U. S. Air Force Regulation 161-35, "Hazardous Noise Exposure," which has been adopted by the DOE. The maximum permissible OEL for steady-state noise is $84 \mathrm{dBA}$ for each 8 hour work period. The OEL for impulse/impact noise is not fixed because the number of impacts allowed per day varies depending on the dBA of each impact. LANL Action Levels for steady-state noise and impulse/impact noise are $80 \mathrm{dBA}$ for each 8 hour day and $140 \mathrm{dBA}$, respectively. The Action Levels trigger the implementation of a personnel hearing conservation program.

Environmental noise exposure is measured outdoors. The sound levels measured vary and are dependent on the generator. The following are typical examples of sound levels (dBA) generated by barking dogs (58), sport events (74), local cars (63), aircraft overhead (66), children playing (65), and birds chirping (54). LANL sources of environmental noise consist of background sound, vehicular traffic, routine operations, and periodic high-explosive testing. Measurements of environmental noise in and around LANL average around $80 \mathrm{dBA}$. Some measurements have evaluated environmental effects from operational and high-explosive detonation noise. For example, the peak noise level measured at the Pulsed High Energy Machine Emitting X-Rays (PHERMEX) facility from a $9 \mathrm{~kg}$ (20 Ib) of trinitrotoluene (TNT) explosion ranged from 140 to $148 \mathrm{dBA}$ at a distance of $229 \mathrm{~m}$ (750 ft). 
The values from limited ambient environmental sampling in Los Alamos County are within the expected sound levels ( $55 \mathrm{~dB}$ ) for outdoors in residential areas. Background sound levels at the White Rock community ranged from 38 to $51 \mathrm{dBA}$ and 31 to $35 \mathrm{dBA}$ at Bandelier National Monument. The minimum and maximum values for the County were $40 \mathrm{dBA}$ and $96 \mathrm{dBA}$, respectively.

Ambient noise levels at this tract are affected primarily by automobiles using DP Road and light industrial activities on surrounding properties. Routine LANL operations cannot be heard at this location. Infrequent high explosive detonations are audible at the DP Road tract.

\subsection{Cultural Resources}

Ios Alamos Coumty is rich in cultural resources that include archeological sites, historic buildings and sites, Traditional Cultural Properties (TCPs), and grave sites. As required under Executive Order 13007 , the four accord Pueblos with whom DOE has formal agreements (Cochiti, Jemez, Santa Clara, and San Ildefonso) have been asked to identify any sacred or TCP issues that may apply to the DP Road tract. LANL has conducted field surveys for cultural resources at the DP Road tract. As a result of these surveys, no cutrural resource sites were found within the boundaries of the DP tract. One archeological site is located in close vicinity to the tract. On November 14, 1996, by formal letter, the State Historic Preservation Officer (SHPO) was asked to concur with a "no effect" determination regarding the proposed action. In response to this formal request, the SHPO concurred with the "no effect" determination on December 12, 1996 (Appendix A).

\subsection{Emvironmental Justice}

Under Presidential Executive Order 12898 of February 11, 1994:

Section 1-1. MMPLEMENTATION.

1-101. Agency Responsibilities. To the greatest extent practicable and permitted by law, and consistent with the principles set forth in the report on the National Performance Review, each Federal agency shall make achieving environmental justice part of its mission by identifying and addressing, as appropriate, disproportionately high and adverse human health or environmental effects of its programs, policies, and activities on minority populations and low-income populations in the United States and its rerritories and possessions, the District of Columbia, the Commonwealth of Puerto Rico, and the Commonwealth of the Mariana Islands."

Minority populations are considered to be all people of color, exclusive of white non-Hispanics and low-income households are those with incomes less than 15,000 dollars per year. DOE is in the process of finalizing procedures for implementing the Executive Order. The manner in which environmental justice issues should be addressed in an environmental assessment is expected to be addressed in the procedures. The analysis of environmental justice in this EA is not intended to establish the direction of DOE's future procedures implementing the Executive Order.

Within an $80 \mathrm{~km}(30 \mathrm{~min})$ zativer LANL about 54 percent of the population is of minority status. In terms of low-income populations, 24 percent of the households have annual incomes below 15,000 dollars. The County is approximately 14 percent minority (the percentage of non-whites, including 
Hispanies, defined by the US Census) and has a median family income of 60,798 dollars (1990 US Census, in 1989 dollars). The County, which would be most directly affected by the Proposed Action, has a higher median family income and a much lower percentage of minority residents than the four surrounding counties.

A though populations that are subject to environmental justice considerations are present within 80 $\mathrm{km}(50 \mathrm{mi})$ of LANL, subsequent activities associated with the Proposed Action would not disproportionately affect low-income, minority, or Native American populations. No adverse effects to environmental justice populations would be expected if the DOE implements the Proposed Action.

In addixion, no disproportionate adverse effects on low-income, minority, or Native American populations are known to occur with the Federal Government as the current owner of the DP Road rract. Therefore, no disproportionate adverse effects to populations subject to environmental justice concerns are anticipated under the No Action alternative. 


\section{D ENVIRONMENTAL CONSEQUENCES}

\subsection{Proposed Action}

This section evaluates the environmental effects of the Proposed Action and the No Action alternative. Each resource identified in Section 3.0 is evaluated in Section 4.0 for probable environmental consequences.

\subsubsection{Socioeconomics}

The County has proposed to use the DP Road tract within the foreseeable future for construction of a new County office building(s), a new warehouse for school supplies, equipment maintenance, and school bus yard, in which case the County would retain its employees and no new direct jobs would be created. Up to 100 employees could be moved from other County job locations. If existing county or school operations and employees simply transfer from their current site in Los Alamos to the proposed tract, there would be no effect on population density and distribution. However, moving these operations to the DP Road tract would free up other County land, making that land available for commercial development. It is anticipated that the newly vacated County property would be developed for commercial or light industrial purposes. Economic development could give the County an alternate source of revenue to replace the current annual allotment of 2.6 million dollars in assistance payments from the DOE that has been recently terminated. The County could generate significant revenue from industrial leasing. A typical commercial building in a good location in Los Alamos could lease for approximately 16 to 18 dollars per square foot per year. Lease of one $2,780 \mathrm{~m}^{2}$ $\left(30,000 \mathrm{ft}^{2}\right)$ building could generate about 510,000 dollars a year in revenue.

If the land is developed for a commercial or professional business park, or for light industry, it is assumed that the DP Road tract could have 3 buildings, each about $2,780 \mathrm{~m}^{2}\left(30,000 \mathrm{ft}^{2}\right)$. At the rate of 1 employee per 200 square feet, there could be about 450 employees on-site. Using an employment multiplier developed by Oak Ridge National Laboratory (ORNL) (Vogt and Das 1996), a calculated 450 “direct" jobs could support another 585 "indirect" jobs. These indirect jobs would be required, at the rate of 1.3 per direct job, to provide the goods and services demanded by the new businesses and their workers. There could also be a construction crew of 40 to 50 people at the tract until completion of the project which could take up to ten years. Construction of a commercial complex, county building, or school yard could provide employment opportunities to local and regional work forces. Employees who reside in the County spend approximately 20 percent of their income locally. For the sake of effects analysis, the average wage for an employee at the DP Road tract is estimated to be 40,000 dollars per year. This could amount to about 3.6 million dollars in local spending that could be achieved under this alternative. Local spending for the procurement of goods and services (including construction materials) would slightly increase economic activity levels in the region. If existing County property that is vacated in favor of the DP Road tract is developed for commercial use, it is assumed that the additional 450 employees and 585 indirect workers would reside in the various communities that comprise the ROI. Because of the size of the ROI, adverse effects on population density and distribution are not expected. If the tract is developed for commercial use, the new jobs

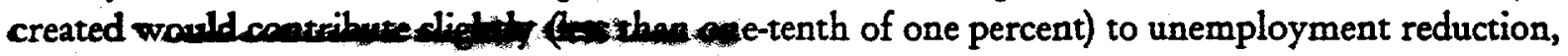
income increases, and economic output in the ROI during construction and operation of the complex. 
Assuming that the estimated 450 "direct" employees occupy the ROI in the same proportion as LANL employees, 48.3 percent, or approximately 217 employees, would potentially reside in the County. Because the estimated 585 “indirect" workers would not necessarily work in Los Alamos, they could be spread throughout the three county ROI more evenly. If 33.3 percent of the "indirect" workers reside in the County, that could amount to an additional 195 residents. This in-migration could increase demand for local goods and services, increasing the strength of the local economy. The effects of these jobs could parially offset job losses that have occurred at LANL in recent years. During 1995 , a reduction in force displaced approximately 915 LANL workers.

\subsubsection{Housing}

If new business opportunities create in-migration, an increase in the demand for housing in the LANL vicinity could stimulate limited housing construction and affect housing costs in the region. Much of the housing demand would be temporary and would primarily affect the renter segment of the market in the County. Over time, market prices would be expected to fluctuate. However, depending on the availability of land for building, housing prices in Los Alamos could remain high and limit the availability of low income houses. There would be an estimated 9,000 vacant housing units available for rent in the ROI by the year 2000 , which would act to minimize long-term effects on the housing market, but low-income residents might be forced to leave the County. If the tract is used solely as a county building or school yard and construction crews are regional or local, no new jobs would be created and there would be no influsence on the current housing market. Given the size and vacancy rate of the ROI, it is anticipated that housing for additional employees would be accommodated within the existing real estate market and no adiditional large-scale residential development would be necessary.

\subsubsection{Utility Demands}

The County estimates that operation of new light industry on the DP Road tract could involve the use of an additional $54,000 \mathrm{kWh}$ (kilowatt hours) per month of electricity, 900 million cubic feet of natural gas per month, and 1,200,000 gallons of water per month. This usage equates to an increase of less than 1 percent in electrical use, less than 2 percent in gas use, and less than 2 percent in water use over the current County usage. Public utilities are not likely to be affected by development or estimated in-migration. It is estimated that existing water, gas, electric, and sewer capacities are adequate for DP Road tract development.

\subsubsection{Land Use}

Transfer of ownership of the DP tract to the County would change the current land use of the tract from undeveloped to developed land. All site structures would be constructed in accordance with applicable County construction codes and used according to zoning ordinances. Portions of the DP Road tract would require installation of major utility lines (sewer, gas, water, and electric) before development could begin. Other portions would require an upgrade of sewer and water utility lines and installation of electric and gas utility lines. A $15 \mathrm{~m}$ (50 ft) easement would be enforced along the buried radioactive liquid waste line that crosses the site. The zoning districts allowed in the general land use categories for the DP Road tract after it is transferred are expected to include: 
- Light Commercial and Professional Business District (C-1). The light commercial and professional business district is intended to accommodate retail, service, and professional uses, compatible with each other, to serve nearby residential districts. The regulations of this district are intended to encourage the growth and development of this type of commercial and professional facility.

- Civic Center Business and Professional District (C-2). The civic center business and professional district is intended to accommodate and promote the commercial and professional development in the center of the community, with a mixture of public, historical, and commercial uses which are compatible with each other, and which provide an attractive and appropriate setting in which county-wide retail and professional services and cultural, recreational, and governmental uses may be undertaken, performed, or pursued. The district regulations are intended to encourage the commercial and professional growth and development of this area.

- Heavy Commercial District (C-3). The heavy commercial district is intended to accommodate commercial uses allowed in the $\mathrm{C}-1$ and $\mathrm{C}-2$ districts and those which generate more traffic and noise. Included are automotive-connected uses such as service stations, repair garages, tire shops, motels and hotels, and uses such as large stores, drive-in or take-out facilities, and commercial recreation establishments.

- Light Tndustrial District (M-1). The light industrial district is intended to accommodate light industrial and certain accessory commercial uses, none of which create noise, smoke, odor, dust, or similar emissions, and which generate a minimum of truck traffic. The regulations of this district are intended to encourage attractively developed sites to ensure further compatibility with adjoining areas of the community.

Within the zoning districts, specific uses are permitted as provided in the use index and their sections of the development code. Any variances would be subject to approval by the County.

An increase in traffic through the intersection of DP Road and Trinity Drive could increase congestion. If the DP Road tract employs approximately 450 people, there could be an increase of approximately 450 vehicles (an increase of approximately six percent in vehicle traffic) using DP Road and the Trinity Drive intersection. Modification to traffic flows and to the intersection would be expected to accommodate changes in traffic patterns. The intersection of Trinity and DP Road may have to be redesigned to reduce traffic congestion. The redesign might require more land. Heavy equipment moving through this intersection during construction could pose additional traffic hazards. If the County and schools occupy this area, there would be county vehicles, trucks, equipment, and school busses using this intersection on a daily basis. During construction, traffic delays might be caused by utility upgrades and access to utility lines. If the tract is developed for commercial use, commuter traffic could aggravate the situation.

Transfer of the DP Road tract would increase the amount of land available to the County for economic development and would allow the creation of additional lands zoned for commercial use. The transfer of this tract would reduce the total acreage at LANL by less than one percent (i.e., 0.1 percent). If the County chooses to develop these lands for light industrial or heavy commercial use, there would be minimal or no change in the current land use of the general neighboring DP Road area. Transfer of the DP Road tract would allow the County to move its current maintenance yard 
warehouses and office building from its present location on Trinity Drive and use the vacated County property for other commercial development.

\subsubsection{Ecological Resources}

The entire tract proposed for transfer is previously disturbed and future development of this land would not adversely affect wildlife, threatened, endangered, or species of concern if the proposed action is implemented. However, about 12 hectares $(28$ acres) of existing disturbed habitat would be lost during development of this tract. No adverse effects on ecological resources from potential population growth are expected because the potential growth would be spread out over the large ROI and should not require large scale residential development.

The habitat in the adjacent canyons to the DP Road tract, which is LANL property, was determined to be capable of supporting three legally protected species: Mexican spotted owl, spotted bat, and peregrine falcon. The Mexican spotted owl was not found by LANL biologists in two previous years of surveys conducted in the suitable habitat surrounding the DP Road tract. Spotted bats have not been detected in four years of surveys in the surrounding suitable habitat. Peregrine falcons have not been observed in the surrounding habitat for two years. As long as potential Mexican spotted owl, spotted bat, and peregrine falcon habitat in Los Alamos Canyon is not destroyed, there should be no effect to the habitat of these species. There are currently no actions anticipated within the canyon that would destroy this habitat.

\subsubsection{Waste Management and Environmental Restoration}

Construction of buildings under the Proposed Action would generate rubble and construction debris which would be expected to be eligible for disposal in the County landfill. Reconfiguring the intersection of Trinity Drive and DP Road may generate rubble which would also be disposed of at the County landfill. When the DP Road tract is developed, as much as $2,700 \mathrm{~m}^{3}\left(3,600 \mathrm{yd}^{3}\right)$ of commercial trash could be generated annually and disposed of at the County landfill. This amounts to an increase of 17 percent in the volume of commercial trash handled by the County landfill, which is a 3.8 percent increase in the volume of total trash handled by the County landfill.

If the County uses the DP Road tract for offices, equipment maintenance, a school bus yard, and warehousing for school supplies, no increase in the total amount of sanitary wastewater would be expected. If the DP Road tract is developed for use as a commercial or professional business park, or for light industry, there could be as many as 450 new employees at the tract and 585 employees who found employment as an indirect effect of the development. Assuming that 33.3 percent of the -indirect" employees work in the County, that means 450 plus 195, or 645 additional employees would be working in the County. Assuming that each employee generates an average of 781 ( 20 gallons) per day of sanitary wastewater while on the job, there would be an additional 49,000 liters (13,000 gallons) per day of sanitary wastewater in the County. This amount is 0.9 percent of the volume of sanitary wastewater currently processed by the County. Some of the employees who work in the County as a result of development of the tract may move into the County from other areas of the state or nation. Any new county residents would generate an additional amount of sanitary wastewater at their residences, with the actual amount dependent on the size of the household and amount of water used for irrigation. 


\section{Emironmental Restoration}

Both of the PRSs at the DP Road tract have been recommended to the EPA for no further action regarding site clean-up. These recommendations are based on PRS published information, such as suspected contamination not existing and the completion of remediation field work. Until the EPA determines that the sites meet regulatory clean-up standards applicable to planned future uses, the sites cannot be developed. Based on LANL and DOE reviews, it is anticipated that the sites currently meet EPA standards. These two PRSs [PRS 0-010(a) and PRS 0-030(b)] are discussed in more detail in section 3.6. Because of the recommendation for no further action, no adverse effects to the development of the DP Road tract would be expected from these two PRSs. However, DOE intends to reserve a right of reentry to these two sites as well as the buffer zone along the eastern and northern boundaries of the DP Road tract and the radioactive liquid waste line easement to accommodate access in the future should it become necessary. A $15 \mathrm{~m}$ (50 ft) easement for future environmental monitoring and clean-up if necessary, would be required for the radioactive liquid waste pipeline on the DP Road tract. Each PRS located on the DP Road tract would be fenced during site construction activities if necessary to prevent any disturbance or development within the PRS. Upon concurrence from appropriate Federal and state agencies that no clean-up actions are required at the PRSs, DOE would reevaluate the need for rewining a right of reentry and for fencing each PRS. Removal of this right would allow for the development of these sites and the buffer zone.

\subsubsection{Aestheties}

Development of the DP Road tract would not alter the commercial or industrial character of the adjoining areas along DP Road although it would extend the area of development farther than the current developed area. Relocation of the County office building and maintenance yards to a less visible site may enhance the appearance of the area of the Los Alamos Townsite they currently occupy. Removal of trees or construction of new buildings would not open up new vistas toward the Sangre de Cristo Mountains, nor would development of the DP Road tract alter the existing mountain view. Locally, about $305 \mathrm{~m}$ (1,000 linear $\mathrm{ft}$ ) of vegetated area along DP Road would be converted to a commercial or industrial appearance. Buildings as high as $15 \mathrm{~m}(50 \mathrm{ft})$ in areas that are currently undeveloped would emphasize the commercial or industrial character of DP Road. Access to the Los Alamos Ranch trail could be dicrupted. No designated scenic areas, parks, or areas of recreational use would be affected. The tract would be expected to remain in a commercial or industrial state for the foreseeable furure.

\subsubsection{Human Health}

Construction activities and normal business operations could involve human health effects from various biological and physical hazards. These effects could range from animal bites and minor injuries, such as curs and scrapes, to more serious injuries or even death of a worker in a major construction accident. The applicable Occupational Safety \& Health Administration (OSHA) regulations would be followod to minimize the hazards to workers. No exposure to radiation would be expected, since the construction and operation of the DP Road tract would not involve radioactive sources during and after development. Any radiolagical exposure to the public from routine operations at TA-21 tritium facilities would be below DOE regulatory standards. The radioactive waste line that crosses the DP Road tract is a small diameter line $(7.5 \mathrm{~cm}$ or $3 \mathrm{in}$ ) and is buried (1.0 to 
$1.5 \mathrm{~m} / 3$ to $5 \mathrm{ft}$ ). No measurable radiation field would be expected at the surface of the ground above the waste line.

The maximum dose rate at the DP Road tract from nearby routine LANL operations would be 0.4 mrem/yr assuming the major radiological air emissions contributor (LANSCE) is operating at full capacity. This dose is well below the DOE public dose standard of $100 \mathrm{mrem} / \mathrm{yr}$ from all exposure pathways. If all 450 estimated new workers were exposed at this rate, it could result in a total dose of 0.18 person-rem per year. The dose-to-risk conversion factor for estimating cancer deaths from exposure to low dose rates of ionizing radiation for members of the public is 500 cancer deaths (latent cancer fatalities) per million person-rem effective dose equivalent ( $5 \times 10^{-4}$ deaths per person-rem). The calculated latent excess cancer fatalities at the DP Road tract to the additional population of 450 public workers would be much less than one (i.e., $9.0 \times 10^{-5}$ ). Therefore, no adverse health risks to public workers would be expected because no latent cancer fatalities or excessive radiation exposures would occur from routine IANL operations.

\subsubsection{Air Quality}

The transfer of the DP Road tract to Los Alamos County would give the County the opportunity to develop the land for industrial or commercial uses. Under a development scenario, the businesses established on the land would not use, generate, or emit radioactive materials. It is anticipated that light industry, such as support service industries, would be developed. No radioactive air emissions would be expected from the establishment of office buildings, warehouses, maintenance buildings, bus barns, and fuel service facilities on the transferred land. Any service industry developed on DP Road tract would have the potential of releasing nonradioactive air emissions such as nitrogen dioxide $\left(\mathrm{NO}_{2}\right.$ ), carbon monoxide (CO), and chemical vapors. These types of activities would be regulated by the applicable Federal, state, and county statutes and ordinances.

Nonradiological air emissions would be produced during the construction of service buildings or County facilities on the DP Road tract. Assuming the construction of three $30,000 \mathrm{ft}^{2}$ buildings, an underground pit for 50,000 gallon gasoline and diesel tanks, and three parking lots, the total air emissions from the construction would be: $\mathrm{NO}_{2}$ (8,930 pounds), $\mathrm{CO}(2,699$ pounds), sulphur dioxide $\left(\mathrm{SO}_{2}\right)$ (787 pounds), particulate matter (PM) (844 pounds), and volatile organic compounds (VOC) (735 pounds). This assumes a ten year construction period. These figures are based on normal construction operations and conservative assumptions. These emissions would not exceed the New Mexico Air Quality standards for criteria pollutants. These emissions were used in an EPA-approved computer model to estimate the concentration of the pollutant constituents at selected public receptor sites. The unimvolved workers and public would not be affected by these emissions primarily because of the distance from the construction sites to the nearest public area and engineering controls. Table 4.1.7.1 lists the New Mexico Air Quality Standards and the air pollutant concentrations at a selected receptor location from the DP Road tract development.

Additional air pollutants would be anticipated from the increased vehicular traffic flow to and from the DP Road tract. Table 4.1.7.2 lists the annual emissions estimates resulting from these vehicles. The pollutant emissions were determined by using an EPA-approved computer model for estimating automobile emissions. For modeling purposes, conservative 1990 EPA emission factors were used and it was assumed that 450 employees at the site would drive a car or light duty truck $23 \mathrm{~km}$ (14 mi) to 
and from the LANL property boundary for 220 working days per year. Based on these emissions, the air quality of LANL and the County would experience a minor deterioration but the air quality atrainment status for the County under the Clean Air Act (CAA) would not be lost.

\subsubsection{Surface Water}

Because stormwater runoff from the DP Road tract would constitute a very small fraction of the runoff from the upstream watershed, surface water quality would not be appreciably affected by the Proposed Action. BMPs to control soil and sediment erosion would be implemented during construction.

Development of the DP Road tract would probably increase stormwater runoff into Los Alamos Canyon. If the County discharges stormwater from a point source then LANL may implement erosion controls, such as the use of hay bales, riprap, and splash pads. Since the DP Road tract is approximately 0.1 percent of the Los Alamos Canyon watershed, the amount of additional runoff from development of the tract would be small compared to that derived from the total upstream watershed area. Therefore, any increase in re-mobilization of contaminated sediments due to increased runoff is expected to be negligible.

Table 4.1.7.1 Estimated Air Pollutant Concentrations from Construction Activities*

\begin{tabular}{|c|c|c|}
\hline 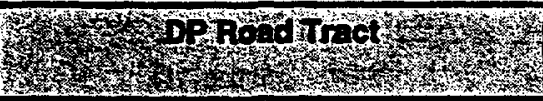 & 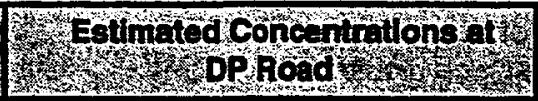 & 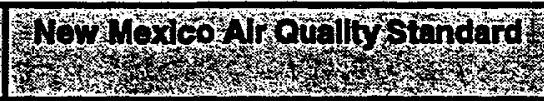 \\
\hline Highest 24-hour Average $\mathrm{NO}_{2}$ & $0.071 \mathrm{ppm}$ & $0.1 \mathrm{ppm}$ \\
\hline Annual Arithmetic Average $\mathrm{NO}_{2}$ & $0.012 \mathrm{ppm}$ & $0.05 \mathrm{ppm}$ \\
\hline Highest 1-hour Average CO & $0.545 \mathrm{ppm}$ & $13.1 \mathrm{ppm}$ \\
\hline Highest 8-hour Average CO & $0.071 \mathrm{ppm}$ & $8.7 \mathrm{ppm}$ \\
\hline Highest 24-hour Average $\mathrm{SO}_{2}$ & $0.005 \mathrm{ppm}$ & $0.1 \mathrm{ppm}$ \\
\hline Annual Arihmetic Average $\mathrm{SO}_{2}$ & $0.001 \mathrm{ppm}$ & $0.02 \mathrm{ppm}$ \\
\hline Highest 24-hour Average TEP:" & $16.0 \mu g / \mathrm{m}^{3}$ & $150.0 \mu g / \mathrm{m}^{3}$ \\
\hline Highest 30-day Average TSP & $15.0 \mu \mathrm{g} / \mathrm{m}^{3}$ & $90.0 \mu \mathrm{g} / \mathrm{m}^{3}$ \\
\hline Annual Geometric Mean TSP & $3.0 \mu \mathrm{g} / \mathrm{m}^{3}$ & $60.0 \mu \mathrm{g} / \mathrm{m}^{3}$ \\
\hline Highest 24-hour Average TSP & $8.7 \mu g / \mathrm{m}^{3}$ & $150.0 \mu \mathrm{g} / \mathrm{m}^{3}$ \\
\hline Highest 30-day Average TSP & $2.3 \mu g / \mathrm{m}^{3}$ & $90.0 \mu \mathrm{g} / \mathrm{m}^{3}$ \\
\hline Annual Geometric Mean TSP & $1.8 \mu \mathrm{g} / \mathrm{m}^{3}$ & $60.0 \mu \mathrm{g} / \mathrm{m}^{3}$ \\
\hline
\end{tabular}

- Construction assumed to occur over a ten year period.

* Total Suspended Particulates 
Table 4.1.7.2 Estimated Annual Vehicular Pollutant Emissions

\begin{tabular}{|c|c|c|}
\hline 1) & 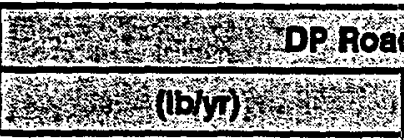 & 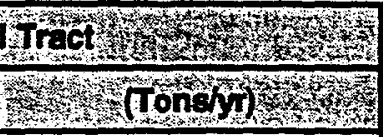 \\
\hline VOC & 23,987 & 12 \\
\hline HC (hydrocarbons) & 10,975 & 5 \\
\hline Co & 183,423 & 91 \\
\hline $\mathrm{NO}_{2}$ & 9,201 & 5 \\
\hline
\end{tabular}

\subsubsection{Noise}

For the sake of analysis, three office buildings, associated parking lots, warehouses, garages, small support buildings, and underground fuel storage tanks are assumed to be established on the DP Road tract The construction of these facilities would entail ground clearing, excavation, foundation laying, exection, and finishing work. The use of heavy equipment for construction, such as front-end loaders, trucks, concrete mixers, and jackhammers would produce noise ranging from 74 to $95 \mathrm{dBA}$ at a distance of $15 \mathrm{~m}(50 \mathrm{ft}$ ) from the work site (Magrab 1975). The finishing work of the buildings would produce noise levels lower than those generated by the heavy equipment (Cantor 1996). Workers would be required to have hearing protection if site specific work produced noise levels above the OSHA accion level of $85 \mathrm{dBA}$ for steady state noise. Engineering controls could be implemented at the site of noise production to reduce noise levels where possible. Noise levels drop in accordance with increased distance from the noise source. No adverse noise effects would be expected to occur to the uninvolved worker and public from the development of the DP Road tract.

\section{No Action Altemative}

\subsubsection{Socioeconomics}

The proposed DP Road tract would remain undeveloped and would offer no employment opportunities or revenue generating opportunities. The tract would not be used for any specific purposes other than to serve as a buffer between LANL operations and public or private property.

Employees who reside in the County spend approximately 20 percent of their income locally. For the sake of effects analysis, the average wage for an employee at the DP Road tract is estimated to be 40,000 dollars per year. This could amount to about 3.6 million dollars in local spending that would not be achieved under this alternative. Also, there would be no procurement of goods, services, or construction materials associated with development and operation of new business. The No Action alternarive would not change current housing market conditions in the County area.

Not transferring the tract would have a negative effect on the County's future revenue potential. The County would have fewer opportunities to find sources of income to offset the loss of dollars in assistance payments from DOE. If the loss of assistance payments is not offset, there may be an effect on human welfare. Some communiry activities may become unavailable, and the level of police, fire protection, mad ouber public services may be reduced if the County cannot afford to maintain current levels of service operation. 


\subsection{Land Use}

Under the No Action alternative, the DOE would not transfer the ownership of the DP Road tract to the County. The tract would remain under DOE control, and the potential effects associated with the Proposed Action would not occur. There would be no change in land use at the DP Road tract. Within the DP Road area, peak-hour traffic consists mostly of work related trips. Thus, barring any other future development, traffic within the area should not increase in the future. The DP Road tract would probably remain undeveloped since the DOE has no current plans for the foreseeable future to move or expand LANL operations into this land area.

\subsubsection{Ecological Resources}

The flora and fauna in and around the DP Road tract would continue to be managed in accordance with LANL policies in the event that the Proposed Action is not implemented. The area would be managed to comply with Federal environmental laws and to reduce wild fire damage. The tract may be mowed, have trees thinned, or be subjected to a controlled burn to reduce the fuel load. The cument ecological tomdinioss on the tract are not expected to change under the No Action alternative.

\subsection{Waste Management and Environmental Restoration}

Under the No Action alternative, no construction waste, operational waste, or new sanitary wastewater would be generated at the land tract. Environmental restoration activities would continue as necessary on the site in accordance with approved EPA and state permits.

\section{2 .5 Aesthetics}

If the land tract remains under DOE ownership and is not developed, no changes in the visual or aesthetic character of the DP Road tract would occur. The aesthetic character of the tract would be retained as undeveloped but previously disturbed forested lands. Under this alternative, access to the Los Alamos Ranch trail would remain unchanged.

\subsection{Human Health}

There would be no change in the potential, chemical, biological, physical, or environmental hazards that could affect human health under this alternative. The minimal amount of radiation exposure to members of the public at the DP Road tract from routine LANL operations would not occur. The tract would remain in its present natural state and continue to serve as a buffer between LANL and the public

\subsection{Air Quality}

Under this alternative the DP Road tract would not be transferred to the County for development. The tract would remain in its present natural state and continue to serve as a buffer between LANL and the public Therefore, no radioactive or nonradioactive air emissions would be generated under this alternatice 


\subsection{Surface Water}

No additional runoff into Los Alamos Canyon would occur under the No Action alternative. Therefore, no change in the potential for contaminant transport would occur, and no change in surface water quality would occur.

\section{Noise}

If tbe DP Road tract remains under DOE ownership and is not developed, no changes in the ambient noise levels would occur. Ambient noise would remain at its current acceptable level.

\subsection{Comparison of Alternatives}

The following summary table (Table 4.3.1) compares the two alternatives presented in this EA and the expected consequences under each alternative. More detailed information as to the anticipated effects under each alternative are discussed in the earlier text in Chapter 4.0.

Table 43.1 Summary of the Potential Effects of the Proposed Action and the No Action Alternative

\begin{tabular}{|c|c|c|}
\hline Sccloeconomics & $\begin{array}{l}\text { Approximately } 100 \text { to } 450 \text { direct jobs } \\
\text { Up to } 585 \text { indirect jobs }\end{array}$ & $\begin{array}{l}\text { No additional persons employed or } \\
\text { income generated }\end{array}$ \\
\hline Land Use & $\begin{array}{l}\text { Maximum of } 12 \text { hectares ( } 28 \text { acres) affected } \\
\text { Increase in vehicular traftic }\end{array}$ & $\begin{array}{l}\text { No land transferred or leased } \\
\text { No change in traffic volume }\end{array}$ \\
\hline Ecologied Resources & $\begin{array}{l}\text { Ecology of site changed to developed land } \\
12 \text { hectares ( } 28 \text { acres) of habitat loss }\end{array}$ & $\begin{array}{l}\text { No change to ecology } \\
\text { No habitat loss }\end{array}$ \\
\hline $\begin{array}{l}\text { Waste Management and } \\
\text { Environmental } \\
\text { Restoration }\end{array}$ & $\begin{array}{l}\text { Commercial and industrial waste managed } \\
\text { per Federal, state, and county regulations } \\
\text { Some future environmental restoration may be } \\
\text { required }\end{array}$ & $\begin{array}{l}\text { No waste generated } \\
\text { Some future environmental restoration } \\
\text { may be required }\end{array}$ \\
\hline Aesthetles & $\begin{array}{l}\text { Construction of } 3 \text { buildings with support } \\
\text { structures and parking lots }\end{array}$ & No changes to land tract \\
\hline Human Health & $\begin{array}{l}\text { Potential physical and biological hazards } \\
\text { Minimal radiation exposure }\end{array}$ & $\begin{array}{l}\text { No adverse effects to humans } \\
\text { Land continues to act as a buffer zone }\end{array}$ \\
\hline Surfece Water & $\begin{array}{l}\text { Increased surface runoff due to development } \\
\text { would be negligible relative to runoff from rest } \\
\text { of watershed } \\
\text { No change in surface water quality expected }\end{array}$ & $\begin{array}{l}\text { No change in runoff } \\
\text { No change in surface water quality }\end{array}$ \\
\hline $\begin{array}{l}\text { Air Quality } \\
\text { (nonradiologican) }\end{array}$ & Emissions below Federal and state standards & No emissions generated \\
\hline $\begin{array}{l}\text { Noise (steady state and } \\
\text { impulse) }\end{array}$ & Noise levels below OEL at public boundary & Noise levels unchanged \\
\hline
\end{tabular}

\subsection{Cumulative Effects}

This section considers the cumulative effects resulting from implementation of the Proposed Action and reasonably foreseeable future actions at the DP Road tract and the adjacent lands at the site. 
Cumulative effects on the environment result from the incremental effect of an action when added to other past, present, and ressonably foreseeable future actions, regardless of what agency or person undertakes such other actions. Cumulative effects can result from individually minor, but collectively significant, actions taking phace over a period of time (40 CFR 1508.7). In addition to the Proposed Action, actions considered for their cumulative effects in this EA include the transfer or lease to the County of additional tracts on DP Road. No changes to LANL operations at TA-21 are included in this analysis since none are projected within the foreseeable future. Some excess buildings at TA-21 could undergo D\&D within the next 10 years. Wastes from this activity would be transported down DP Road to the LANL waste management area at TA-54. These D\&D activities could release small amounts of particulate air emissions such as dust. Toxic or radioactive air emissions would not be expected as hazardous materials would be removed prior to D\&D operations.

There have been some preliminary discussions between DOE, LANL, and the County about the possibility of transferring to the County several tracts of land along DP Road (but not part of the Proposed Action). Together the additional parcels occupy approximately 18 hectares (43 acres). If these tracts are transferred or leased to the County and developed within the next ten years for commercial or light industrial use, there would be a variety of environmental effects similar to those addressed under the Proposed Action. The purpose of the proposed and future foreseeable land conveyances would be to help the County become economically self-sufficient. Developing additional tracts on DP Road would increase the financial base for the County in the same way that the Proposed Action would. By planning the development of all tracts in a unified way, it would be possible to maximize the benefit to the County. The cumulative economic benefit of jointly developing all the tracts under consideration may be greater than the sum of economic improvement that would occur if each tract were developed without regard for the type of development in other tracts. DOE would perform additional NEPA analyses prior to any decisions to convey additional DP Road properties.

Development of additional tracts on DP Road would require modifications to the existing County water, gas, electrical, sewer, and waste management systems. Implementation of the Proposed Action and development of additional tracts along DP Road would also increase the load to all of these systems and the cumulative effect would need to be evaluated in light of existing capacity to deliver the necessary services to customers. Based on the available acreage, it is projected that increases of less than 10 percent to the capability or capacity of each system would be required to accommodate all of the possible new developments. No adverse effects are anticipated from population growth associated with the development of the DP Road tract and adjacent tracts because the potential growth would be spread out over the hrge ROI and should not require large scale residential development.

Development of additional tracts on DP Road would increase the traffic along DP Road. Implementation of the Proposed Action would also increase traffic. The Proposed Action affects an area about half the size of the additional tracts, and would probably generate about half as much traffic. The cumulative effect of these actions may require the redesign of the DP Road and Trinity Drive intersection and some engineering controls to direct the additional traffic in the area.

People working at the DP Road tract would be able to hear the noise created by detonations at LANL projects such as the Dual A ris Rodiographic Hydrodynamic Test (DARHT) facility, the PHERMEX facility, and other research projects involving high explosives. Although the detonations occur on LANL property remote from residential areas, the noise from these activities can occasionally exceed 
the Ios Alamos County daytime residential noise guidelines (i.e., more than 75 dBA) (DOE 1995). However, the noise is the impulse type of short duration and therefore would be only a transient disturbance to workers in the developed tract. Workers would also be subject to vehicular traffic noise, which is exempted under Los Alamos County noise regulations (Los Alamos County Code, Ch. 8.28.030).

The broader picture of how all planned LANL projects implemented over the next ten years may affect the human environment will be the subject of the LANL Site-Wide Environmental Impact Statement (SWEIS) which is currently under development. The LANL SWEIS will include an analysis of the cumulative effects of LANL operations and projects under several alternatives.

The DOE may consider the conveyance of other parcels located variously across Los Alamos and Santa Fe Counties, both within LANL's boundaries and without. Any such proposals will be analyzed through the NEPA compliance process prior to any decision(s) to proceed with implementation of the action(s). One recently processed lease of DOE property is the Los Alamos Airport lease to the County. This lease of an existing airport for continued same-use was categorically excluded under NEPA from the preparation of either an EA or EIS. 


\section{D POTENTIAL ACCIDENT SCENARIO}

In order to consider potential effects of accidents in the DOE decision making process, one catastrophic accident scenario involving radioactive materials at LANL's TA-21 facilities was analyzed for its effect on the future land use that is proposed as a consequence of implementing the Proposed Action. The accident scenario was developed to evaluate credible accident scenarios that could affect the public and workers in and around the DP Road tract after development. The details of the accident analysis are described in Appendix B.

Accidents resulting from the use of the DP Road site were also considered. However, because future site-specific uses are known in a general manner only, a reasonably credible accident scenario could not be developed for the DP Road tract. Site activities would be conducted according to applicable state, local, and Federal regulations that govern or control the amount and types of materials allowed onsite. Therefore, it is unlikely that a credible catastrophic accident that could affect workers, members of the public, and employees at TA-21 would occur on the DP Road tract in the future.

The accident scenario for this tract was developed to evaluate potential effects on the public located within the DP Road tract. This accident analysis is based on reasonable and health protective assumptions consistent with those recommended by the DOE for similar analyses used in Safety Analysis Reports (SARs). The accident analysis presented in this EA is a hypothetical accident that is unlikely to actually occur. An earthquake of sufficient magnitude to collapse the tritium facility at TA-21 was selected for analysis. This scenario is a credible accident that would result in the greatest release of radioactive material that could affect the occupants of the DP Road tract. Therefore, it bounds the potential radiological effects of other possible accident scenarios.

The postulated accident is assumed to be initiated by a seismic event effecting the tritium facility located at the far east side of TA-21. The earthquake is assumed to collapse the tritium facility building, purting virtually all the tritium inventory at risk. The greatest material at risk (MAR) is a combination of the operations and storage inventories. The operations inventory is composed of $223 \mathrm{~g}$ with approximately $100 \mathrm{~g}$ in storage vaults, for a total of $323 \mathrm{~g}$ of MAR. A portion of the MAR is assumed to be released in the form of an oxide during the accident because the oxide form of tritium poses a greater radiological health hazard. The total MAR that could be released as oxidized tritium is assumed to be approximately $176 \mathrm{~g}$. The remaining $147 \mathrm{~g}$ would either be released as unoxidized tritium gas which poses a much lower radiological health hazard or it would remain bound to equipment or contained in various process traps and sieves.

It is assumed that an earthquake of high magnitude capable of collapsing the tritium facility would have a return period of less than 500 years. With a return rate of 500 years, this type of accident will have an occurrence frequency of between $10^{-2}$ to $10^{-4}$, which makes it an "unlikely" event. An "unlikely" event falls into Consequence Likelihood Category III. In this category, the occurrence frequency is between 1 in 100 years and 1 in 10,000 years, or at least once in 10,000 similar facilities operated for one yex.

The accident $25 s u m e s .1760$ of oxidized tritium is released into the atmosphere in respirable aerosol form. The wind would carry the plume to the receptor site 1,000 meters $(3,300 \mathrm{ft})$ away at the DP Road Iract area where the public inhales the contaminants. The DP Road tract would have several 
buildings which would be staffed by non-LANL employees. The employees would be considered members of the public.

The radiation dose to a member of the public was calculated using standard parameters, such as source term, dispersion factor, exposure time, and breathing rate. The calculated dose to a member of the public at the DP Road tract from this accident would be 13.2 rem based on the conservative tritium oxide release estimates and the unlikely event of an earthquake occurring.

The calculated dose to the public at the DP Road tract under this accident scenario is convertible to a population cancer risk. The dose-to-risk conversion factor for estimating cancer deaths from exposure to low dose rates of ionizing radiation for members of the public is 500 cancer deaths (latent cancer fatzlities) per million person-rem effective dose equivalent ( $5 \times 10^{4}$ deaths per person-rem). If each of the 450 estimated new workers received a dose of $13.2 \mathrm{rem}$, it would result in a total dose of 5,940 person-rem. The calculated excess latent cancer fatalities at the DP Road tract from this accident for public workers would be 2.97. Therefore, adverse health effects to the public could result from the hypothetical accident scenario developed for implementation of the Proposed Action. 


\section{D REGULATORY REQUIREMENTS AND CONSULTATIONS}

DOE would be responsible for compliance with environmental restoration regulations at the DP Road tract The County would be responsible for seeking and obtaining applicable Federal, state, and local permits for activities at the DP Road tract. Regulations implementing the CAA, Federal Water Pollution Control Act (Clean Water Act), RCRA, Safe Drinking Water Act, Toxic Substances Control Act, Emergency Planning and Community-Right-to-Know Act, Endangered Species Act, and others may apply to activities at the tract.

On November 14, 1996, DOE formally requested that the SHPO concur with a finding of "no effect" on cultural resources. DOE consulted with the SHPO regarding a cultural resource site located near the DP Road tract. No effect to the site is anticipated from the implementation of the Proposed Action. Additionally, the four accord Pueblos with whom DOE has formal agreements (Cochiti, Jemez, Santa Clara, and San Ildefonso) have been asked to identify sacred or TCP issues that may apply to the DP Road tract. On December 12, 1996, the SHPO concurred with the DOE finding of "no effect" (Appendix A).

DOE also consulted with the County of Los Alamos and invited their participation in the prepararion of this EA. Information regarding proposed future land use was provided by the County, as well as information regarding the existing County environment (Appendix A). 
This Page Intentionally Left Blank 


\subsection{REFERENCES}

ARC, Inc. 1993: Architectural Research Consultants, Inc., "County of Los Alamos Business Park Feasibility Study, March 1993," Architectural Research Consultants, Inc. report ARC 3/93.

BEA 1995: Bureau of Economic Analysis 1990, "Bureau of Economic Analysis Regional Projections to 2040, Vol II, Metropolitan Statistical Areas," U.S. Department of Commerce, Washington, D.C., Oct. 1990, as reparted in "Draft PEIS for Stockpile Stewardship and Management," Feb. 1996.

Cantor 1996 L. Cantor, “Environmental Impact Assessment,” McGraw-Hill, Inc., second edition.

Commerce 1991: U.S. Department of Commerce, Economics and Statisticians Administration, Bureau of Census, "1990 Census of Population and Housing: Summary Population and Housing Characteristics - New Mexico," 1990-CHP-1-33, August 1991, as reported in "Environmental Assessment, Proposed Chemical and Metallurgy Research (CMR) Building Upgrades." Los Alamos National Laboratory. Los Alamos, NM, Nov. 1995.

DOE 1996: U.S. Department of Energy, “Environmental Assessment for the Low Energy Demonstration Accelerator, Technical Area 53," U.S. Department of Energy report DOE/EA 1147.

DOE 1995: U.S. Department of Energy, “Dual Axis Radiographic Hydrodynamic Test Facility Final Environmental Impact Statemert, "Volume 1, page 5-5; U.S. Department of Energy report DOE/EIS0228.

DOE 1979: U.S. Deparment of Energy, "Final Environmental Impact Statement: Los Alamos Scientific Laboratory Site, Los Alamos, New Mexico," U.S. Department of Energy report DOE/EISD018.

ICRP 1991: International Commission on Radiological Protection, "1990 Recommendations of the International Commission on Radiological Protection," Publication 60, Pergamon Press, New York, NY.

IA County 1995: Los Alamos County Landfill Weight Records for 1995, Review of County records.

IA County 1994: Los Alamos County Development Code, December 1994.

Iangen Planning 1994: “Business Park Study for the Incorporated County of Los Alamos, August 19, 1994, " Langen Planning report.

LANL 1996: Los Alamos National Laboratory, "Environmental Surveillance at Los Alamos During 1994, Los Alamos National Laboratory report LA-13047-ENV.

Harman 1996: Linda Hartman, “RFI repart for Sircth Street Warehouse: PRS 0-030(b), 0-004, 0-033(b), and 0-010(b)," Los Alamos National Laboratory report LA-UR-96-1749. 
Magrab 1975: Edward B. Magrab, "Environmental Noise Control," a Wiley-Interscience Publication. Jahn Wiley \& Sons, New York, NY.

McLin 1995: Stephen G. McLin, "Determination of 100-Year Floodplain Elevations at Los Alamos National Laboratory," Los Alamos National Laboratory report LA-12195-MS.

Nyhan et 2l. 1978: J.W. Nyhan, L.W. Hacker, T.E. Calhoun, D.L. Young, “Soil Survey of Los Alamos County, New Mexico," Los Alamos Scientific Laboratory report LA-6779-MS.

Pearman and Grumbly 1993: D.M. Pearman and T.P. Grumbly, Transmittal of Final Draft "Forging the Missing Link: a Resource Document for Identifying Use Options."

ULI 1995: Urban Land Institute, "Urban Land Institute Market Profiles 1995: North America," Urban Land Institute, Washington, D.C., 1995, as reported in "Draft PEIS for Stockpile Stewardship and Management," Feb. 1996.

Vogt and Das 1996: D.P. Vogt and Sujit Das, "Estimation of Indirect Local Economic Impacts of Alternative Clean-up Options for K-25," Working Paper, Energy and Global Change Analysis Section, Oak Ridge National Laboratory. 


\section{LOS ALAMOS COUNTY}

coonerrecound

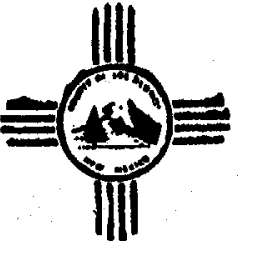

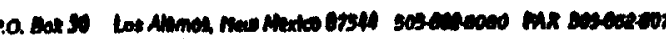

Odober 22, 1998

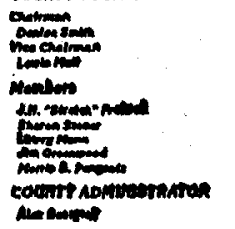

Mr. G. Thomas Todd, Area Manager

Depurtment of Energy

Los Alamos Aroa Ong

L28 35th Street 10354

Dear Mr. Toda:

Subject Land Use for Resewch Park and DP Road Parcole

This letter is to provide clartication on the land use(s) for the parcols to be leased or

transfernod to Los Alemos County. The county has a procses for determining the

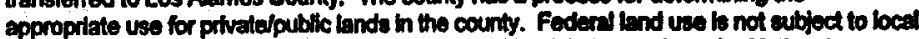

land use regulations oxcopt as provided by fedena Legiatafion such as the National

Envionmental Pollcy Act. The County understands DOE may need to places cortain

limitations on the use of the land in the short-andtong term as certain uses moy inpect

priorily operations at LAVi

The County process starts with tho comprehensive land use plan with general land use categories. Based on the adjacent land wes, sito location, and the intenstity of dovelopment the general land uses for the Roseerch Perk and the DP roed percests world be Business

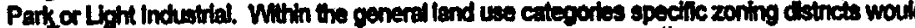
be allowed as provited in the devolopment code. The zoning diatricts allowed in the general land use catogories for the Ronearch Pank and the DP rand percele would be Profoestonal Oficos (P-O), Liott Commerctal and Professional Busineses (C-1), Civic Center Busineses and

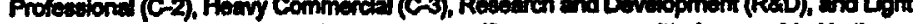

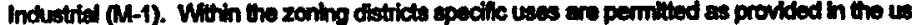
index and othor sections of the dovetopment cods. This hrometion has proviousty been

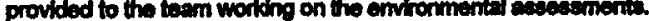

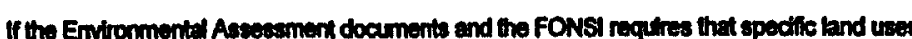

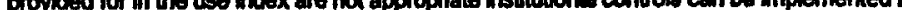

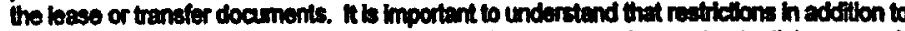

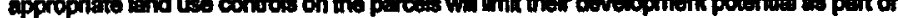

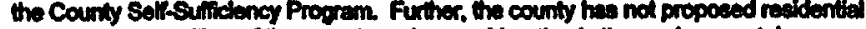

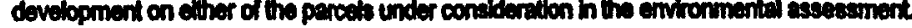

"A Consolidated Clty and County Government"
The County has ofiurod on mumerous occistons to work with the team preparting the

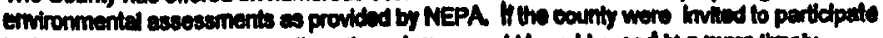

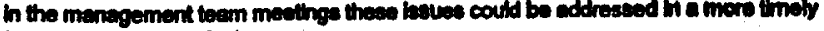
Contion with leve contivion.

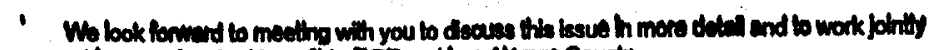
in haves of musual beneit b DOE and Los Alimos County.

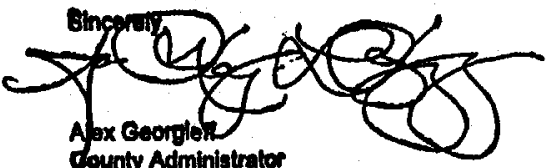

- Los Alamos County Counall

Kevin Fonner, Comminity Development Director "

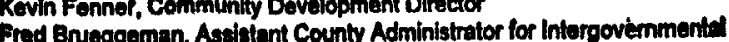
Rovations 


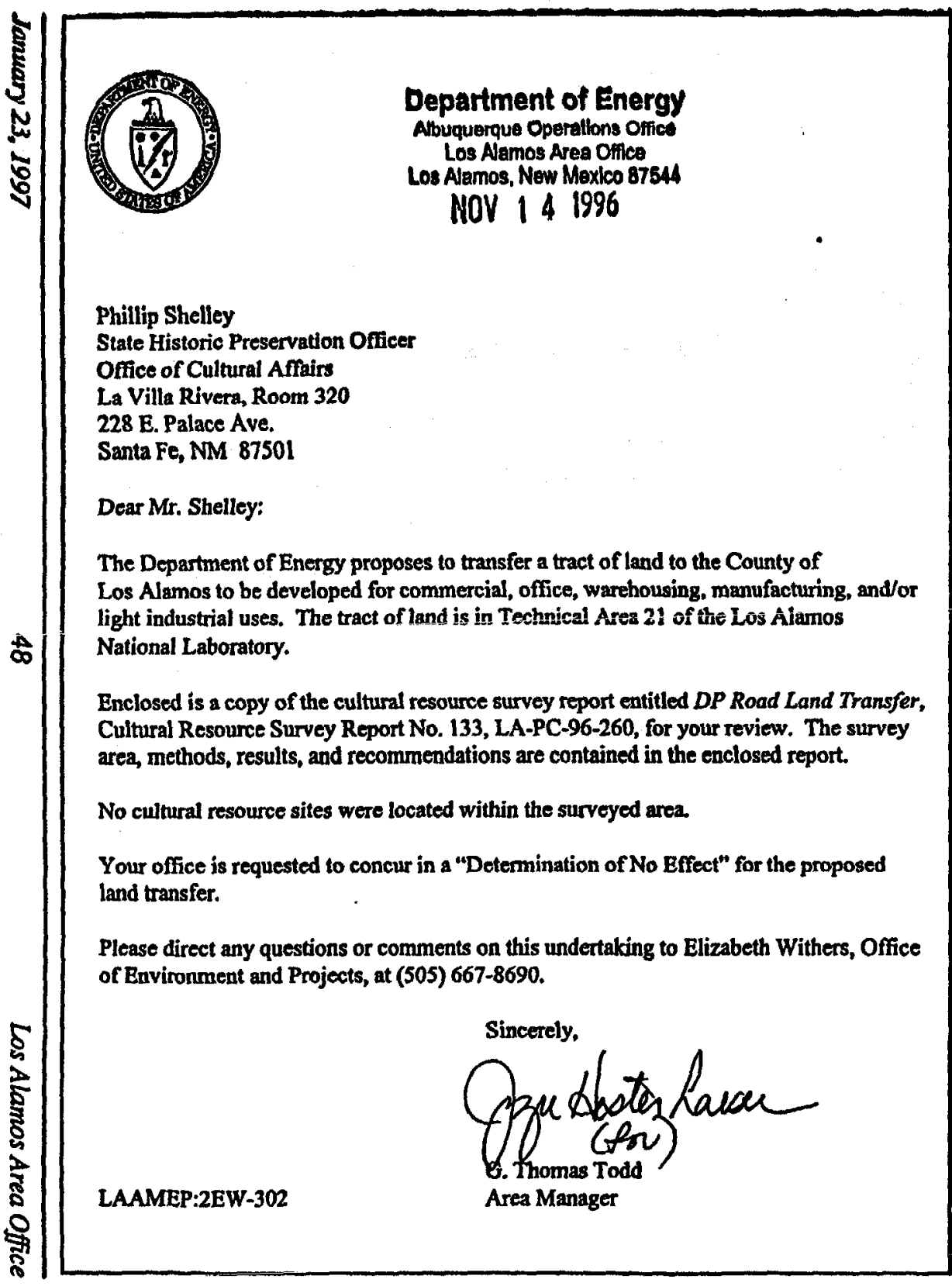

Philltp Shelley

2

Coneurnence in a Delemination of No Erfoct

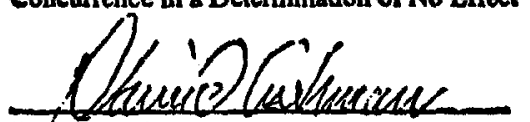

State Historic Preservation Officer

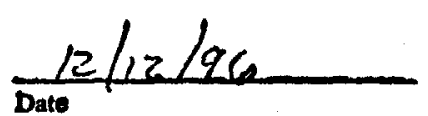

Comments:

\section{Enclosure}

ec w/o enclosure:

The Honorable Elmer Torres

Govemor

Pueblo of San Iildetonso

Route 5, Box 315-A

Santa Fe, New Mexico 87501

The Honorable Joseph C. Quintana

Governor

Pueblo of Cochit

P. O. Box 70

Cochiti Pueblo, New Mexico 87072

The Honorable Randolph Padilla

Governor

Pueblo of Jemez

P. O. Box 100

Jemez Pueblo, New Mexico 87024

The Honorable Gilbert Tafoya

Governor

Pueblo of Santa Clara

P. O. Box 580

Espafiola, New Mexico 87532

Elizabeth Withers, LAAMBP, LAAO

Robert Enz, Scientech, LAAO

Demis Erickson, ESH-DO, LANL, MS-K491

Beverly Larson, ESH-20, LANL, MS-MB87 


\section{APPENDIX B}

\section{Potenfial LANL Accident Scenario Affecting DP Road Tract}

Preliminary Scenario Description: This scenario is based on a postulated accident at the Tritium Science and Fabrication Facility (TSFF) that would affect the DP land transfer tract. The elements of the accident scenario are as follows:

- A light industrial park would be constructed on land tracts south of DP Road.

- An accident occurring at the TSFF at TA-21 that would cause the release of radiological material.

- The consequences resulting from this radiological release would have the potential to affect the transferred land tract and the proposed businesses and personnel located there.

\section{Scenario Description}

\section{Description of tbe Activity}

A proposed light industrial park would be built on land that is transferred from DOE to the County. The land ract on which the park would be built are located south of DP Road. It is assumed that the business park will include several businesses which will be staffed by employees who are considered to be members of the public.

The postulated accident at TSFF is assumed to be initiated by a seismic event. The earthquake is assumed to collapse the TSFF building, putting virtually all the tritium inventory at risk. The maximum material at risk (MAR) prior to the hypothetical accident is a combination of the operations inventory $223 \mathrm{~g}$ and approximately $100 \mathrm{~g}$ in storage vaults for a total of $323 \mathrm{~g}$ of MAR.

\section{Assumptions and Source Term}

In developing the source term from the TSFF accident scenario, it is assumed that all the tritium on Ubeds is released and oxidized cue to the dispersal of the uranium tritide ( 150 grams). This is a very conservative assumption because of the substantial construction of the U-beds. It is assumed that 15 grams of the tritium (surface contamination) in the salt line is at risk in this scenario. It is also assumed that all of the tritium gas ( 100 grams) is released but only $10 \%$ of that ( 10 grams) is oxidized upon release due to ignition from rending metal. It is assumed that approximately $1 \%$ of the tritium gas not immediately oxidized ( $1 \mathrm{gram}$ ), will be oxidized by various atmospheric and bioconversion processes. The unoxidized fraction ( 89 grams) will not contribute to the off-site dose because of its relatively low dose conversion factor compared to the oxidized fraction. Eight grams is subtracted from the total MAR as being on molecular sieves and not subject to rapid release, and 50 grams is subtracted as being on zirconium hydride beds in the metal/tritium recovery process which will not spontaneously release with a breach of the contaminant.

Since an and the building remaining standing, therefore, the dispersion factor used is assumed to be for a ground-level release. 


\section{Accident Scenario Frequency Analysis}

It is assumed that an earthquake of the magnitude that would collapse TSFF would have a return period of less than 500 years. With a return rate of 500 years, this type of accident will have a frequency of occurrence of between $1 \times 10^{-3}$ to $1 \times 10^{-5}$ which makes it an "unlikely" event.

\section{Accidemt Scenario Release Source Term}

The exposure to radiological material resulting from an accident is dependent on the amount of material released. It is assumed that for this accident scenario that the material at risk (MAR) is the amount that could be released in the oxidized form $(176 \mathrm{~g})$. For material released in the form of respirable particulate matter or oxides, the amount of material released or source term can be estimated by the following expression:

$$
\text { Source Term }=\text { MAR } \times \text { DR } \times \text { SA } \times \text { LPF }
$$

MAR = amount of material at risk

DR - damage ratio (the fraction of the MAR affected by the accident conditions)

SA - specific activity $(\mathrm{Ci} / \mathrm{g})$

IPF - leak path factor (building failure due to collapse is assumed)

For this accident the source term is estimated to be:

$$
\text { Source Term }=(176 \mathrm{~g})(0.5)\left(9.6 \times 10^{3} \mathrm{Ci} / \mathrm{g}\right)(1.0)=8.5 \times 10^{5} \mathrm{Ci}
$$

\section{Accident Scenario Consequences}

The exposure portion of the consequence analysis is for the maximum exposed individual (MEI) of the public located at the proposed business park south of DP road. The dose for the MEI is a product of the individual's intake of contaminants and the dose conversion factor for those contaminants. The individual's intake is a product of the source term, dispersion factor, and the breathing rate. A standard breathing rate of $3.3 \times 10^{4} \mathrm{~m}^{3} / \mathrm{sec}$ is used in the exposure calculation. The intake is estimated by the following general expression:

$$
\text { Intake }=\text { Source Term } \times \text { Dispersion Factor } \times \text { Breathing Rate }
$$

Table 1 records the results for these intake calculations for the public MEI. After the intakes have been calculated, the resulting doses to the MEI is calculated by use of the following equation:

$$
\text { Dose }=\text { Intake } \times \text { Dose Conversion Factor }(\mathrm{EDE})
$$

The dose conversion factors are provided as effective dose equivalent (EDE) in rem/ $\mathrm{Ci}$. Dose calculation results are presented in Table 2. 


\section{Table 1. Intake Calculations}

\begin{tabular}{|c|c|c|c|c|c|}
\hline Whoptor & 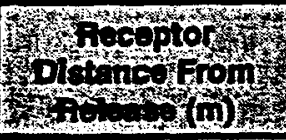 & 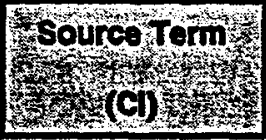 & Dispersion par & 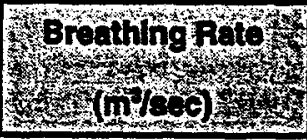 & (1) \\
\hline olic & 1,000 & $5 \times 10^{5}$ & $5 \times 10^{-4}\left(\mathrm{~s} / \mathrm{m}^{3}\right)$ & $3.3 \times 10^{-4}$ & $1.4 \times 10^{-1}$ \\
\hline
\end{tabular}

Table 2. Dose Calculation

\begin{tabular}{|c|c|c|c|}
\hline Peceptor & Sintake (C) & Dose Conversion Factor EDE (rem/C) & Dose (rem) \\
\hline Public & $1.4 \times 10^{-1}$ & 95 & 13.2 \\
\hline
\end{tabular}

\section{Risk Assessment}

The calculated dose to the public at the DP Road tract under this accident scenario is convertible to a population cancer risk. The dose-to-risk conversion factor for estimating cancer deaths from exposure to low dose rates of ionizing radiation for members of the public is 500 cancer deaths (latent cancer fatalities) per million person-rem effective dose equivalent (5 $10^{-4}$ deaths per person-rem). If each of the 450 estimated new workers received a dose of $13.2 \mathrm{rem}$, it would result in a total dose of 5,940 person-rem. The calculated excess latent cancer fatalities at the DP Road tract from this accident for public workers would be 2.97. Therefore, adverse health effects to the public could result from the hypothetical accident scenario developed for the Proposed Action.

\section{Table 3. Radiological Exposure Risk}

\begin{tabular}{|c|c|c|c|}
\hline 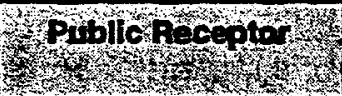 & Won & Dose-poliskronverson & 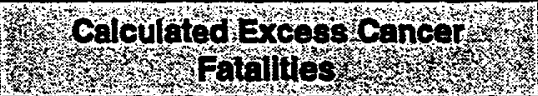 \\
\hline 450 persons & 13.2 & $5 \times 10^{-4}$ & 2.97 \\
\hline
\end{tabular}

